NASA Technical Memorandum 105164 AIAA-91-3433

\title{
Nondestructive Evaluation Tools and Experimental Studies for Monitoring the Health of Space Propulsion Systems
}

Edward R. Generazio

Lewis Research Center

Cleveland, Ohio

Prepared for the

Conference on Advanced Space Exploration Initiative Technologies cosponsored by the AIAA, NASA, and OAI

Cleveland, Ohio, September 4-6, 1991 


\title{
NONDESTRUCTIVE EVALUATION TOOLS AND EXPERIMENTAL STUDIES FOR
}

\section{MONITORING THE HEALTH OF SPACE PROPULSION SYSTEMS}

\author{
Edward R. Generazio \\ National Aeronautics and Space Administration \\ Lewis Research Center \\ Cleveland, Ohio 44135
}

\section{SUMMARY}

The next generation of space propulsion systems will be designed to incorporate advanced health monitoring and nondestructive inspection capabilities. This report provides an overview of background and information on space propulsion systems at both the programmatic and technical levels. Feasibility experimental studies indicate that nondestructive evaluation tools such as ultrasonic, eddy current and x-ray may be successfully used to monitor the life limiting failure mechanisms of space propulsion systems. Encouraging results were obtained for monitoring the life limiting failure mechanisms for three space propulsion systems; the degradation of tungsten arcjet and magnetoplasmadynamic electrodes; presence and thickness of a spallable electrically conducting molybdenum films in ion thrusters; and the degradation of catalyst in hydrazine thrusters.

\section{INTRODUCTION}

The next generation of space propulsion systems will be designed to incorporate advanced health monitoring and nondestructive inspection capabilities. The nondestructive evaluation (NDE) community identified several questions that should be addressed. The following key questions were raised during the April 2-5, 1990 meeting of the Joint Army-NavyNASA-Air Force (JANNAF) Nondestructive Evaluation Subcommittee (NDES):

(1) What types of space propulsion systems are being considered?

(2) What are the principles of operation of these systems?

(3) Who is developing and/or researching space propulsion systems?

(4) How are inspections and reliability assessments performed on the ground and in orbit?

(5) Do the space propulsion systems require health monitoring?
(6) What are the possible failure modes for these systems?

(7) Have the reliabilities of these space propulsion systems been determined?

This report describes technological driver missions supporting space programs that are developing chemical, electric and nuclear propulsion systems. The types of propulsion systems being considered, their principles of operation and known failure modes, and the developers are identified. The propulsion systems characteristics are described in sufficient detail to identify life-limiting features and opportunities for nondestructive testing and health monitoring. However, the reader should be aware that not all aspects of the propulsion system that required health monitoring and nondestructive evaluation are covered. For example, the failure modes of space-based nuclear generators or solar panels that supply power in the form of electric energy for electric propulsion systems are not discussed. Space propulsion systems are at various stages of development; therefore, many questions, such as those concerned with reliability and failure modes, remain unanswered. Three feasibility experiments were performed for evaluating the capabilities of NDE tools for monitoring the health of chemical and electrical propulsion systems.

\section{TRANSPORTATION FOR FUTURE SPACE SCIENCE MISSIONS}

The actual vehicles and propulsion systems that are to be used for future space missions have, in most cases, not been determined. The specific propulsion system and vehicle being considered for a particular mission changes as the mission develops and matures. Therefore, these propulsion systems are not predetermined and fixed but are essentially moving targets. Before the NDE community can assist and affect the development of these advanced propulsion systems, they must latch onto these moving targets by understanding the programmatic thrusts, the path of the development, and current status of these systems. 
Technological challenges have been identified (Ref. 1) that are driving the development of advanced space propulsion systems. The following set of missions presents technological challenges that must be addressed to meet national space transportation needs:

(1) Modern expendable launch systems of small and medium capacity

- Payload weight: 20000 to $50000 \mathrm{lb}$ low Earth orbit (LEO)

- High reliability

- Low cost

- Improved payload-to-lift mass

(2) Unmanned heavy-lift launch capability to LEO

- Payload weight: greater than $100000 \mathrm{lb}$

- Payload envelop: as unrestricted as feasible

- Cost: substantial reduction over current systems (full or partial reusability will be determined by economic tradeoffs)

(3) Reusable orbital transfer system to raise payloads from LEO to higher altitude, sunsynchronous or geostationary orbit and to return them

- Geostationary payload weight: greater than $20000 \mathrm{lb}$

- Payload envelope: as unrestricted as feasible

- Robotics: capable of interfacing with intelligent front-end for routine servicing operations

(4) Advanced space transportation system to replace the space shuttle after the turn of the century

- LEO payload weight: from $20000 \mathrm{lb}$ to potentially greater than $100000 \mathrm{lb}$

- Payload envelope: as unrestricted as feasible

- Automation and robotics: used to reduce turnaround time and mission costs, with special emphasis on self diagnostics

- Tradeoffs will be made between "Shuttle II" and the transatmospheric

- Aerospace Plane

(5) High-energy interplanetary transfer system to meet objectives of the National Commission on Space

- High specific impulse, high-thrust, long-life propulsion systems to minimize duration of trips to Mars (e.g., $10000 \mathrm{lb}(44000 \mathrm{~N})$ or greater thrust, 800 -sec specific impulse)

- High specific impulse, long-life propulsion systems for planetary scientific missions (e.g., very low thrust, greater than

1000-sec specific impulse)

- Nuclear-electric or direct thrust engines are candidates for these missions

- Hybrid power and propulsion systems are another attractive option

Some of the specific technology-driver missions for space science for the mid-1990's follow:

The Earth Observing System (EOS) (Fig. 1), with three EOS platforms in sun-synchronous orbits, is designed to study the Earth's atmosphere. It is believed that automated or robotic servicing will be required at the operational altitude of the platform during its 20-yr life.

The Large Deployable Array (LDR) (Fig. 2) is an astronomical observatory design that will operate in the 30-to $1000-\mu \mathrm{m}$ range.

It is expected that maintenance will occur on a 3-yr schedule.

During a Mars Sample Return Mission (MSR) (Fig. 3), samples at several depths and at widely dispersed sites on the Martian surface will be obtained and returned to Earth in a pristine condition.

\section{SPACE EXPLORATION INITIATIVE}

On February 16, 1990, President Bush approved policy for the Space Exploration Initiative. The goal of this initiative (Ref. 2) is to place Americans on Mars by the year 2019. The initiative includes both lunar and Mars program elements, as well as robotic science missions. The near-term focus will be on technology development. This will be done by searching for new and innovative approaches and technology, and by investing in high-leverage, innovative technologies with potential to make major impact on cost, schedule, and performance. Mission, concept, and analysis studies will be done in parallel with the technology development.

A baseline program architecture will be selected after several years of defining two or more reference architectures while developing and demonstrating broad technologies (Refs. 3 and 4). NASA will be the principle implementing agency, whereas the Department of Defense and Department of Energy will have major roles in technology development and concept definition. Some of the space programs discussed below have been absorbed or replaced by this Space Exploration Initiative. 


\section{SPACE PROGRAMS}

The National Aeronautic and Space Administration (NASA) has several programs that require advanced, space-based propulsion systems. These propulsion systems may be quite different from those used in Earth-to-orbit launch vehicles. Each program has a different set of mission requirements that drives the development of different space propulsion systems (Refs. 5 to 7). For example, the propulsion system used to keep the Space Station Freedom (Fig. 4) in orbit will be quite different from that used for a manned Mars mission. To answer the questions presented earlier, we must examine the NASA space programs that have advanced space propulsion needs. Each program identifies specific mission requirements to be met by the propulsion system (Ref. 8).

During the development of a space transportation system, propulsion studies and vehicle studies must be iterated until the propulsion requirements are defined for the vehicle. Following the definition of the propulsion requirements, mission-focused propulsion system studies identify the specific required propulsion system. Depending on the acceptable mission scenario, very different propulsion systems and vehicles can result in successful space transfer. However, since studies have not matured sufficiently, we are unable to specify what propulsion system will be used for an actual mission. Mission scenario studies indicate that advanced, reliable, long life, low weight, efficient, high power, and variable-thrust space propulsion systems are needed.

Space propulsion systems may be based on electrical, chemical, or nuclear processes (Table I). The design, operation, maintainability, reliability, failure modes, health monitoring, and mission requirements for these propulsion systems will vary considerably. Therefore, it is natural to examine each of these systems on the basis of the physical process used to produce thrust. Before the types of propulsion systems being considered, developed, or used are described, it is appropriate to identify the programs that support the development of these propulsion systems.

\section{Chemical Propulsion Program}

Project Pathfinder (Ref. 9) from the NASA Office of Aeronautics and Space Technology 1 (OAST) is a research and technology program designed to make new missions in space exploration possible and strengthen the technology base in support of the civil space program. Pathfinder has a distant horizon that is reached by building on the space shuttle and space station programs. Pathfinder addresses technologies that support a range of space

TABLE I. - SPACE PROPULSION SYSTEMS

\begin{tabular}{|l|l|l|}
\hline Engine type & \multicolumn{1}{|c|}{$\begin{array}{c}\text { Principle of } \\
\text { operation }\end{array}$} & \multicolumn{1}{|c|}{ Propulsion system } \\
\hline Chemical & Recomposition & $\begin{array}{l}\text { Liquid oxygen/ } \\
\text { liquid hydrogen } \\
(\text { LOX/H }) \text { thruster } \\
\text { Hydrazine thruster }\end{array}$ \\
\hline Electrical & Electrostatic & $\begin{array}{l}\text { Ion thruster } \\
\text { Resistojet, arcjet, } \\
\text { microwave thruster } \\
\text { Magnetoplasmadynamic }\end{array}$ \\
\hline Nuclear & Nuclear fission & Solid core rocket \\
Gas core rocket
\end{tabular}

$\overline{{ }^{1} \text { Now NASA }}$ Office of Aeronautics and Exploration Technology (OAET). 
missions including: a return to the Moon to build an outpost (Fig. 5), piloted missions to Mars (Fig. 6), and continuing exploration of Earth and the other planets.

Project Pathfinder has four major components:

(1) Exploration Technology, (2) Space Operations,

(3) Humans-in-Space, and (4) Transfer Vehicle Technology. The Exploration Technology, Space Operations, and Humans-in-Space components include planetary rover development, surface power, remote sample acquisition, optical communications, autonomous rendezvous and docking, resource processing, in-space assembly and construction, cryogenic fluid depots, space nuclear power, extravehicular suits, human performance, and closed-loop support systems. The Transfer Vehicle Technology is of particular interest because it supports transportation to and from geostationary Earth orbit, the Moon, Mars, and other planets. Specific goals of the Transfer Vehicle component include significant reduction in the mass that missions require for launch into low Earth orbit and in transit, as well as reductions in the time required for transit. The key elements of the Transfer Vehicle Technology thrust are the chemical transfer propulsion research, cargo vehicle propulsion development, high-energy aerobraking development (Fig. 7), autonomous lander development, and fault-tolerant systems.

The Transfer Vehicle Technology thrust led to the initiation of the NASA OAST Pathfinder Chemical Transfer Propulsion Program (Refs. 10 and 11). This program was initiated to provide the technology to design and develop highly reliable, reusable cryogenic transfer vehicle engines that are fault tolerant, and have long lives. They will be high-performance, liquid oxygen/liquid hydrogen $\left(\mathrm{LOX} / \mathrm{H}_{2}\right)$ expander cycle engines for space-based transfer vehicles and Moon and Mars landers.

\section{Electric Propulsion Program}

NASA OAST's Propulsion, Power, and Energy Division supports an electric propulsion program (Refs. 12 to 15) for a broad class of missions. Three types of electric propulsion systems are being developed (Refs. 12 to 29): . electrostatic (ion), electrothermal (resistojet, arcjet, microwave, and radiowave), and electromagnetic (magnetoplasmadynamic, or MPD). Resistojets are currently used on geosynchronous communications satellites.
Nuclear Propulsion Program

In 1987 the Air Force Systems Command reinitiated a Direct Nuclear Propulsion Program (Refs. 1, 30, and 31). The goals of this program are to develop a high-impulse, high-thrust, low-weight propulsion system. This propulsion system would be used for orbital transfer vehicles, fast launch interceptors, intercontinental ballistic missiles, and other missions. In October 1990 NASA's Propulsion, Fower and Energy Division initiated a Nuclear Thermal Propulsion Program. A Nuclear Electric Propulsion Program will begin October 1991.

\section{PROPULSION SYSTEM CHARACTERISTICS}

The operating characteristics of chemical, electrical and nuclear propulsion systems are quite different (Ref. 32). Thrust and specific impulse can be used for making general comparisons between propulsion systems. Table II indicates the range of thrust $T$ and specific impulse $I_{\text {sp }}$ for electrical, chemical, and nuclear propulsion systems. Thrust is the amount of force that a propulsion system generates. The greater the thrust, the greater the acceleration of the vehicle. Specific impulse (in seconds) is the thrust (in Newtons) that can be obtained from an equivalent rocket which has a propellant weight flow rate (in Newtons per second) of unity. (Specific impulse is somewhat analogous to the number of miles per gallon of fuel for automobiles.) Electric propulsion systems have lower thrust capabilities than chemical or nuclear propulsion systems do. Chemical propulsion systems yield the highest thrust levels available to date. However, direct nuclear propulsion is expected to yield greater thrust levels than chemical propulsion. The specific impulse for electrical resistojets and arcjets are comparable to chemical $\mathrm{LOX} / \mathrm{H}_{2}$ and hydrazine propulsion systems. The ion, MPD, and nuclear propulsion systems have the highest specific impulses, and they can exceed those of other systems by an order of magnitude.

Classes of propulsion systems that will be needed to meet mission requirements can be identified from table II and from preliminary mission propulsion requirements. High specific impulse engines, such as ion, MPD, and nuclear propulsion systems, will be needed for interplanetary transfer. Low thrust engines, such as resistojet, arcjet, and hydrazine 
TABLE II. - THRUST AND SPECIFIC IMPULSE

\begin{tabular}{|c|c|c|c|}
\hline Engine type & Propulsion system & $\begin{array}{c}\text { Specific impulse, } \\
\mathrm{I}_{\text {sp }} \\
\text { seconds }\end{array}$ & $\begin{array}{c}\text { Thrust, } \\
\text { T, } \\
\text { Newtons }\end{array}$ \\
\hline Chemical & $\begin{array}{l}\mathrm{LOX} / \mathrm{H}_{2} \text { thruster } \\
\text { Hydrazine thruster }\end{array}$ & $\begin{array}{l}300 \text { to } 500 \\
280 \text { to } 300\end{array}$ & $\begin{array}{l}(0.100 \text { to } 2222) \times 10^{3} \\
(180 \text { to } 360) \times 10^{-3}\end{array}$ \\
\hline Electrical & $\begin{array}{l}\text { Ion thruster } \\
\text { Resistojet } \\
\text { Arcjet } \\
\text { Microwave thruster } \\
\text { Magnetoplasma- } \\
\text { dynamic (MPD) }\end{array}$ & $\begin{array}{c}3500 \\
290 \text { to } 380 \\
400 \text { to } 1100 \\
200 \text { to } 600 \\
1500 \text { to } 8000\end{array}$ & $\begin{array}{c}(65 \text { to } 510) \times 10^{-3} \\
(180 \text { to } 490) \times 10^{-3} \\
(10 \text { to } 212) \times 10^{-3} \\
50 \text { to } 200\end{array}$ \\
\hline Nuclear & $\begin{array}{l}\text { Nuclear thermal } \\
\text { rocket (NTR) }\end{array}$ & 800 to 1200 & $(333$ to 1000$) \times 10^{3}$ \\
\hline
\end{tabular}

engines, are needed for station keeping and drag makeup for orbiting systems and for manned maneuvering units. High-thrust engines are needed for cargo orbit and orbital maneuvering vehicles (Fig. 8).

\section{BASIC PRINCIPLES OF SPACE PROPULSION SYSTEMS}

In this section, each of the candidate propulsion systems is discussed, the operating principles and current developmental status of each system are indicated, and any system features that limit the useful lifetime of these propulsion systems are highlighted. The specific researchers that are developing these systems can be identified in the references quoted.

\section{Chemical Propulsion}

Hydrogenoxygen thruster. - The hydrogen oxygen $\left(\mathrm{LOX} / \mathrm{H}_{2}\right)$ thruster uses chemical recomposition to produce thrust. Hydrogen and oxygen are injected, mixed and ignited in the combustion chamber (Fig. 9, Refs. 33 to 40). The ignited mixture burns to form hot gaseous reaction products that are accelerated via the throat and nozzle assembly to produce thrust. The RLIOA-3-3A engine, which is the only upper-stage, $\mathrm{LOX} / \mathrm{H}_{2}$ thruster in operation, was designed to be expendable. Life-limiting failure modes have not been observed for reusable, space- based, gaseous $\mathrm{O} / \mathrm{H}$ thrusters (Fig. 10), therefore, the lifetimes are not known.

Hydrazine thruster. - The hydrazine thruster is based on the principle of chemical decomposition (Fig. 11). The propellant, hydrazine, is injected into the catalyst bed (Refs. 41 to 46), and the catalyst causes the hydrazine to spontaneously decompose into $\mathrm{NH}_{3}, \mathrm{~N}_{2}$, and $\mathrm{H}_{2}$ gases. The gases are exhausted via the nozzle to produce thrust. In an augmented hydrazine thruster (Fig. 12), the gases are heated further before exiting. "The service life of these thrusters is limited by the useful life of the catalyst bed. The failure is due to a break down of the catalyst into fine particles that are eliminated via the exhaust.

\section{Electric Propulsion}

Resistojet. - A schematic diagram of a resistojet is shown in Fig. 13. Propellant is heated via a resistively heated heat exchanger. The heated propellant $\left(1400^{\circ} \mathrm{C}\right)$ is expanded and exhausted via the nozzle to produce thrust (Refs. 47 to 66 ). The propellant may be introduced to create a vortex flow pattern within the heat exchanger. The candidate propellants are $\mathrm{CO}_{2}$ (carbon dioxide), $\mathrm{CH}_{4}$ (methane), $\mathrm{H}_{2}$ (hydrogen), $\mathrm{NH}_{3}$ (ammonia), $\mathrm{N}_{2}$ (nitrogen), steam, and $\mathrm{N}_{2} \mathrm{H}_{4}$ (hydrazine). State-of-the-art resistojets are shown in Figs. 14 to 18 . Heater mass, and material 
surface changes, and grain growth rates affect the life of these systems. The thruster life also depends on the propellant used.

Arcjet. - The arcjet (Fig. 19) uses an electric arc to heat the propellant directly. Here the propellant is passed between two electrodes while an arc is struck and maintained to heat and expand the propellant. Then the heated propellant (hydrazine, hydrogen, or ammonia) is exhausted through the nozzle to produce thrust (Refs. 67 to 89). Several designs using different materials have been studied (Figs. 20 to 23).

The lifetime of an arcjet is limited by electrode, nozzle, and injector wear. The electrode wear may be in the form of spalling due to thermal shocks or localized melting from high current densities. Electrode wear may also occur when there are chemical incompatibilities. The arcjet reliability is not known; however, the starting reliability indicates that a large number of starts does not affect the steady state performance.

Microwave thrusters. - Microwave and radiowave thrusters heat the propellant without the use of electrodes (Refs. 90 to 96). The microwaves heat the propellant (argon, nitrogen, or helium) in the discharge chamber (Fig. 24), and the heated propellant $(2000 \mathrm{~K})$ exits via the nozzle to produce thrust. Nozzle melting and erosion have limited the thruster life.

Ion thruster. - An ion thruster is shown in Fig. 25. Xenon or mercury vapor is ionized in an ionization chamber, and the positively charged particles are accelerated via the accelerator grid. Then, neutralizer injects electrons to neutralize the accelerated, positively charged particles. This accelerated, neutralized mass produces the thrust (Refs. 97 to 124). The magnets, the screen, and accelerator grids make up the ion optic system (Figs. 26 and 27) that collimates the accelerated particles. The typical path that the ions follow is also shown in Fig. 25. Unexpected extinctions of the discharge are due to thermal design and lack of ignition control. Sputter erosion of the discharge chamber, screen, baffle, and cathode limits the life of ion thrusters. Metallic flakes, which form as a result of this sputter erosion, may spall and short out the ion optics by bridging the gap between the screen and accelerator grids. The cathode tubes also oxidize and deform during thruster operation.

Magnetoplasmadynamic (MPD) thruster. - The magnetoplasmadynamic thruster (Figs. 28 to 31 ) looks similar to the arcjet; however, the principles of operation are quite different. The MPD thruster is based on electromagnetic principle as opposed to the arcjet, which is based on electrothermal principle. The propellant is ionized by the current flow between the anode and cathode. This current flow induces a magnetic field that causes expansion of the arc and acceleration of the ionized gas to produce thrust (Refs. 125 to 136). The propellants used are xenon, argon, hydrogen, helium, ammonia, neon, nitrogen, and lithium. The lifetimes of these propulsion systems are limited by erosion of the cathode and insulator.

\section{Nuclear Propulsion}

Two types of nuclear propulsion systems are being developed: a nuclear thermal propulsion (NTP) system and a nuclear electric propulsion (NEP) system (Refs. 102 and 136). The NEP system uses a nuclear reactor to provided electric power to an electric propulsion system (e.g., an MPD or ion thruster). The NTP systems may use either a solid core reactor (SCR) or a gas core reactor (GCR).

Solid core nuclear thermal rocket. - A solid core nuclear propulsion system (Refs. 137 to 146) uses fissioning solid uranium carbide particles to heat hydrogen (Figs. 32 to 36 ). The hydrogen is heated as it flows down the coolant tubes of the fuel elements. Then it is accelerated via the nozzle to produce thrust. Both fuel and support elements are used in forming the SCR. The rate of reaction in the SCR is controlled by the graphite matrix supporting the uranium carbide particles that make up the fuel elements and by $\mathrm{ZrH}$ moderators contained in the support elements. Corrosion of the graphite moderator/heat exchanger by hot hydrogen limits the life of the SCR propulsion systems.

Gas core nuclear thermal rocket. - Gas core nuclear propulsion systems (Refs. 147 to 152 ) use fissioning uranium gas/plasma to heat hydrogen. Two types of gas core (open- and closed-cycle) rockets are being considered. An open cycle, porous wall, 
spherical gas core rocket engine uses the nuclear thermal energy of the fission gas/plasma to heat an envelope of hydrogen propellant (Fig. 37). The hydrogen expands and flows out of the nozzle to produce thrust. Both uranium and hydrogen are exhausted in this open-cycle system. A closed-cycle nuclear light bulb (NLB) rocket heats hydrogen that is behind thermally transparent and cooled $\mathrm{SiO}$ or $\mathrm{BeO}$ walls (Figs. 38 to 40 ). This arrangement isolates the uranium fuel and fission products from the propellant exhaust.

\section{HEALTH MONITORING SCHEME FOR SPACE PROPULSION SYSTEMS}

There are three levels of monitoring (Fig. 41) that needs to be done for successful health monitoring of space propulsion systems (Ref. 153.). At the first level, system wide global monitoring is done continuously with a limited amount of sensors. This level of monitoring is used to identify global changes in the response of the propulsion system. If a significant variation is identified or flagged then additional sensors are activated for Level 2 monitoring. Here analysis of the sensors response is used to identify areas that require local inspection (Level 3). Specialized tools are then used to fully characterize the suspect area. These tools may be operated manually or remotely and they may be deployable.

A list of nondestructive evaluation tools that may be used at any monitoring level is shown in Fig. 42. The variable that each of these tools can monitor is also shown. The most common NDE tools are acoustic emission, borescope, computed tomography, eddy current, holography, sherography, thermography, ultrasonic and $\mathrm{x}$-ray radiography. Many of these tools can monitor the same variable. For example, when looking for cracks, acoustic emissions, borescope, computed tomography, eddy current, strain gauge, ultrasonic and $\mathrm{x}$-ray radiography can be used successfully. In practice, however, only one or two of these techniques will be used. A good example is a long narrow width crack in a nonconducting ceramic. Eddy current, x-ray, borescope, and computed tomography techniques will be of limited value. Ultrasonic evaluation will yield superior results because it is sensitive to the acoustic impedence difference of the crack boundary.

Figure 42 also indicates that any one tool is sensitive to several variables. In particular, ultra- sound is sensitive to the presence of cracks, delaminations, stress, porosity, thickness, grain size, recrystallization, interlaminar and fiber-to-matrix bond quality. Again, in practice only a few of these variables will be affected. For example, a monolithic material mechanical cycled at low temperatures (a temperature below grain growth or recrystallization) should not exhibit porosity, grain size, recrystallization, delaminations, interlaminar and fiber-to-matrix bond quality variations. However, residual stress and cracking will be expected.

In general, the expected failure modes will guide the selection of the appropriate NDE tools.

\section{APPLICATIONS OF NDE FOR SPACE PROPULSION SYSTEMS}

\section{Ultrasonic Monitoring Electrode Shape for Arcjet} and Magnetoplasmadynamic Thrusters

It has been shown previously that the life of the arcjet and magnetoplasmadynamic thrusters is limited by the degradation of the electrodes. The tips of these electrodes tend to melt at the high current densities used. In a feasibility study an ultrasonic signal is used to monitor the condition of the electrode tip. The experimental setup is shown in Fig. 43. An ultrasonic signal is sent down the length of the electrode to interact with the tip. The signal echoes off of the tip and returns to the same ultrasonic transducer. In an effort to simulate electrode wear due to melting, the tip is ground away while being monitored with ultrasonics. (Note: It has been observed in a separate study that there is a slight change in the ultrasonic signal due to increased electrode temperatures up to $2100^{\circ} \mathrm{C}$.) The damaged area of the tip is characterized by the diameter $\mathrm{D}$ of the ground region (Fig. 43). An increase in damage corresponds to an increase in the diameter D of the ground region.

The ultrasonic amplitude and change in transit time are shown in Fig. 44. A typical wave form is also shown. The amplitude increases while the transit time decreases as diameter of the damage zone increases. The increase in amplitude is due to the decreased focal scattering at the tip. That is the ultrasound is now being backscattered in a planar manner due to the flatness of the ground region. The decrease in transit time is due to the decreased length of the electrode. The length of the electrode 
$(12.7 \mathrm{~cm})$ decreased by $70 \mu \mathrm{m}$ or about 0.0006 percent.

Eddy Current Monitoring of Molybdenum Film Thickness for Ion Propulsion Systems

The ion propulsion systems life is limited by the spalling of metallic flakes that short out the electric potential between the accelerating and screen grids. The growth, thickness and presence of these flakes may be monitored with eddy currents. As a demonstration, a molybdenum wedge shaped slab was formed on a glass substrate (Fig. 45). A $3 \mathrm{MHz}$ eddy current probe was scanned across the substrate side as shown. The eddy current response increases with increasing thickness. Here, the molybdenum thickness varied from 150 to $1000 \mu \mathrm{m}$. The increase in the eddy current for increased thickness is due to the increased loading that the additional molybdenum mass puts on the probe. The frequency of the eddy currents can be increased to be sensitive for thinner films a few $100 \AA$ thick.

\section{X-ray or Radiation Monitoring of Catalyst \\ Loss for Hydrazine Thruster}

The life of hydrazine thrusters is limited by loss of the catalyst material during use. The catalyst bed is made up of particles that have been coated with a catalyst material. Representative materials are aluminum oxide particles coated with platinum. The weight percent of the catalyst ranges from about 0.3 to 50.0 depending on the materials used.

An aluminum oxide pellet (Fig. 46) was formed by mechanically pressing aluminum oxide - platinum power mixtures. One half of the pellet mold was loaded with 10 percent weight of platinum and the other half was loaded with 15 percent weight platinum. This arrangement represents a hydrazine thruster that has lost approximately one-third of its catalyzing material.

An x-ray radiograph clearly shows the variations in the amount of the catalyst present. The left side (the lighter half) of the pellet corresponds to the lower platinum catalyst weight percent. This intensity of the $\mathrm{x}$-ray is sensitive to both the $\mathrm{x}$-ray absorption properties and the total mass. Here the decreased loading of 5 percent weight of the catalyst shows a dramatic decrease in absorption of $x$-rays. This type of monitoring may also be done by making intensity measurements at a point at a fixed distance from a radioactive or $\mathbf{x}$-ray source. That is, $\mathbf{x}$-ray imaging is not required.

\section{DISCUSSION AND SUMMARY}

There are many space propulsion systems that are being developed. The principles of operation vary considerably between systems. Each system has its own particular types of failure modes. However, it is clear that material losses and material microstructural changes are the dominant mechanisms that affect the lifetimes of these advanced systems. These material variations are identified as mass losses due to electrical sputter erosion, oxidation or chemical erosion, and microstructural changes such as melting and grain growth. Feasibility experimental studies indicate that nondestructive evaluation tools such as ultrasonic, eddy current and x-ray may be successfully used to monitor the life limiting mechanisms of space propulsion systems. Encouraging results were obtairied for monitoring the life limiting failure mechanisms for three space propulsion systems; the degradation of tungsten arcjet and magnetoplasmadynamic electrodes; presence and thickness of a spallable electrically conducting molybdenum films in ion thrusters; and the degradation of catalyst in hydrazine thrusters.

The difference between past propulsion systems and the next generation of space propulsion systems will be the incorporation of health monitoring strategies. Lifetime estimates have been obtained for some of these space propulsion systems. However, nonintrusive methods for monitoring and verifying the propulsion system's "age" and health need to be developed. In addition, the reliabilities for most of these propulsion systems remain in question, and methods of determining these reliabilities at a reasonable cost have not been developed.

These space-based propulsion systems provide a rich field of opportunity for nondestructive evaluation and health monitoring researchers. Nondestructive evaluation and health monitoring researchers vill impact the development of space propulsion systems as they become active in the development of future directions. 


\section{REFERENCES}

General

1. Space Technology to Meet Future Needs. NASA CR-181473.

2. Finn, T.T: The Space Exploration Initiative, $A$ Long-Range, Continuing Commitment, NASA Office of Aeronautics, Exploration and Technology, NASA Headquarters Washington, DC, Sept. 1990.

3. Report of the 90-Day Study on Human Exploration of the Moon and Mars, NASA Headquarters, Washington, DC, Nov. 1989.

4. Human Exploration of Space: A Review of NASA's 90-Day Study and Alternatives. National Research Council, National Academy Press, Washington, DC, 1990 (Also, NASA CR-186394).

5. Prerequisite Requirements for Exploration Class Missions, NASA Office of Exploration, Z-MAS-PRD-003, Version 2.1, NASA Headquarters, Washington, DC, May 27, 1988.

6. Ride, S.K.: Leadership and America's Future in Space. NASA TM-89638, 1987.

7. Pioneering the Space Frontier, The Report of the National Commission on Space. Bantam Books, Inc., NY, 1986.

8. Palaszewski, B.; and Engelbrecht, C.: Lightweight Spacecraft Propulsion System Selection, AIAA Paper 87-2022, June 1987.

9. Project Pathfinder, Technology Benefits Assessment, Offices of Aeronautics and Space Technology, NASA Headquarters, Washington, DC, Nov. 1987.

10. Hannum, N.P.; Berkopec F.D.; and Zurawski, R.L.: NASA's Chemical Transfer Propulsion Program, AIAA Paper 89-2298, July 1989 (also NASA TM-102298).
11. Hannum, N.P.; Berkopec F.D.; and Zurawski, R.L.: The Pathfinder Chemical Transfer Propulsion Program. NASA TM-102084, 1989.

12. Stone, J.R.; Byers, D.C.; and King, D.Q.: The NASA Electric Propulsion Program. NASA TM-101324, 1988.

13. Byers D.C.; and Wasel, R.A.: The NASA Electric Propulsion Program. AIAA Paper 87-1098, May 1987 (also NASA TM-89856).

14. Stone, J.R.: NASA Electrothermal Auxiliary Propulsion Technology. AIAA Paper 86-1703, June 1986 (also NASA TM-87281).

15. Byers, D.C.: The NASA Electric Propulsion Program. 17th International Electric Propulsion Conference, Japan Society for Aeronautical and Space Sciences, Tokyo, 1984, pp. 1-9.

16. Silva T.H.; and Byers, D.C.: Orbital Transfer of Large Space Structures with Nuclear Electric Rockets. AAS Paper 80-083, Mar. 1980.

17. Byers, D.C.; Terdan F.F.; and Myers, I.T.: Primary Electric Propulsion for Future Space Missions. Conference on Advanced Technology for Future Space Systems, Technical Papers, American Institute of Aeronautics and Astronautics, AIAA Paper 79-0881, 1979.

18. Deininger, W.D.; Vondra, R.J.; and Schafer, W.J.: Electric Propulsion for Constellation Deployment and Spacecraft Maneuvering. AIAA Paper 88-2833, July 1988.

19. Sauer, Jr., C.G.: Application of Solar Electric Propulsion To Future Planetary Missions. AIAA Paper 87-1053, May 1987.

20. Byers, D.C.; and Stone, J.R.: Status of High Power Electric Propulsion Technology. Transactions of the Fifth Symposium on Space Nuclear Power Systems, M.S. El-Genk and M.D. Hoover, eds., CONF-880122-SUMM, 1988, pp. 337-340. 
21. Nock, K.T.: TAU - A Mission to a Thousand Astronomical Units. AIAA Paper 87-1049, May 1987.

22. Byers, D.C.: Characteristics of Primary Electric Propulsion Systems. AIAA Paper 79-2041, Oct. 1979 (also NASA TM-79255).

23. Sponable, J.M.; and Penn, J.P.: Electric Propulsion for Orbit Transfer - A NAVSTAR Case Study (Has Electric Propulsion's Time Come?). AIAA Paper 87-0985, May 1987 (also J. Propulsion Power, vol. 5, no. 4, July-Aug. 1989, pp. 445-451).

24. Byers, D.C.: Upper Stages Utilizing Electric Propulsion. JANNAF Propulsion Meeting, Vol. 5, K.L. Strange, ed., CPIA-PUBL-315-VOL-5, Chemical Propulsion Information Agency, Larel, MD, 1980, pp. 69-84. (Available NTIS, AD-A087063.)

25. Aston, G.: Advanced Electric Propulsion for Interplanetary Missions. Aerospace Century XXI: Space Flight Technologies (Advances in the Astronautical Sciences, Vol. 64., Pt. 2), Univelt Inc., 1987, pp. 609-626.

26. Silva T.H.; and Byers, D.C.: Nuclear Electric Propulsion System Utilization for Earth Orbit Transfer of Large Space Structures. AIAA Paper 80-1223, June 1980.

27. Berry, W.: Status Report on the ESA Sponsored Electric Propulsion Developments. AIAA Paper 85-1997, Sept. 1985. (Also, ESA Bulletin, no. 45, Feb. 1986, pp. 24-33.)

28. Wiley, R.L. et al.: Space Reactor Power 1986: A Year of Choices and Transition. Proceedings of the Twenty-first Intersociety Energy Conversion Engineering Conference, Vol. 3, American Chemical Society, Washington, DC, 1986, pp. 1411-1415.

29. Stone, J.R.: Recent Advances in Low-Thrust Propulsion Technology. AIAA Paper 88-3283, July 1988. (also NASA TM-100959).
30. Bohl, R.J.; Boudreau J.E.; and Kirk, W.L.: History of Some Direct Nuclear Propulsion Developments Since 1946. Space Nuclear Power Systems 1987, Vol. 2, M.S. El-Genk and M.D. Hoover, eds., Orbit Book Co., Malabar, FI, 1987, pp. 467-473.

31. Bohl, R.J.; and Boudreau, J.E.: Direct Nuclear Propulsion: A white paper. Submitted to Air Force Rocket Propulsion Laboratory, 1987.

32. Sutton, G.P.: Rocket Propulsion Elements: An Introduction to the Engineering of Rockets. John Wiley and Sons, 1963.

\section{Hydrogen/Oxygen Thruster}

33. Jones, R.E. et al.: Space Station Propulsion. NASA TM-100216, 1987.

34. Jones, R.E.: High- and Low-Thrust Propulsion Systems for the Space Station. AIAA Paper 87-0398, Jan. 1987 (also NASA TM-88877).

35. Jones, R.E. et al.: Space Station Propulsion System Technology. Acta Astronaut., vol. 15, no. 9 , Sept. 1987 , pp. 673-683.

36. Richter, G.P.; and Price, H.G.: Proven, LongLife Hydrogen/Oxygen Thrust Chambers for Space Station Propulsion. NASA TM-88822, 1986.

37. Smith, W.W. et al.: Development and Design Aspects of a 5-Pound Thrust RCS Rocket Engine Module. AIAA Paper 70-654, June $\llbracket 970$.

38. Robinson, P.J.; and Rosenthal, S.E.: A Proven 25-lbF $\mathrm{H}_{2} / \mathrm{O}_{2}$ Thruster for Space Station Auxiliary Propulsion. AIAA Paper 86-1560, June 1986.

39. Senneff, J.M.; and Richter, G.P.: A Long-Life 50lbf $\mathrm{H}_{2} / \mathrm{O}_{2}$ Thruster for Space Station Auxiliary Power. AIAA Paper 86-1404, June 1986. 
40. Herkert, B.J. et al.: 25-LBF Gaseous Oxygen/ Gaseous Hydrogen Thruster for Space Station Application. 1986 JANNAF Propulsion Meeting, Vol. 1, K.L. Strange and D.S. Eggelston, eds., CPIA-PUBL-455-VOL-1, Chemical Propulsion Information Agency, Laurel, MD, 1986, pp. 539-546.

\section{Hydrazine Thruster}

41. Roberts, C.R.: Life Demonstration Test of an Uprated Augmented Catalytic Thruster. AIAA Paper 87-0996, May 1987.

42. McKevitt, F.X.; and Schwam, F.R.: Design, Performance, and Operational Scaling Criteria for Electrically Augmented Hydrazine Thrusters. AIAA Paper 84-1234, June 1984.

43. Shankar, V.; Ram, K.A.; and Bhaskaran, K.A.: Experimental Investigations of the $10 \mathrm{~N}$ Catalytic Hydrazine Thruster. Acta Astronaut., vol. 12, no. 4, Apr. 1985, pp. 237-249.

44. Sackheim, R.L.; and Howell, G.W.: Trends in Propulsion Systems for Geosynchronous Satellites. 14th International Symposium on Space Technology and Science, M. Nagatomo, ed., AGNE Publishing, Tokyo, Japan, 1984, pp 245-254.

45. McKevitt, F.X.: Design and Development Approach for the Augmented Catalytic Thruster (AC1), AAIA Paper 83-1255, June 1983.

46. Gross, R.L.: Evaluation of the Walter Kidde 1335 NT. (300 lbf) Monopropellant Thruster. 1979 JANNAF Propulsion Meeting, Vol. 3, K.L. Strange, ed., CPIA-PUBL-300-VOL-3, Chemical Propulsion Information Agency, Laurel, MD, 1979, pp. 523-544.

\section{Resistojets}

47. Carney, L.M.; Bailey,A. B.: Experimental Evaluation of Resistojet Thruster Plume Shields. NASA TM-101363, 1988.
48. Whalen, M.V.; and Grisnik, S.P.: Compatibility of Grain-Stabilized Platinum with Candidate Propellants for Resistojets. AIAA Paper 85-2014, Sept. 1985 (also NASA TM-87118).

49. Manzella, D.H. et al.: The Effect of Ambient Pressure on the Performance of a Resistojet. J. Propulsion, vol. 5, no. 4, July-Aug. 1989, pp. 452-256.

50. Breyley, L. et al.: Effect of Nozzle Geometry on the Resistojet Exhaust Plume. AIAA Paper 87-2121, June 1987.

51. Miyake, C.I.: Radiative Resistojet Performance Characterization Tests. (REPT-84-R-958, Rocket Research Corp; NASA Contract NAS3-23868), NASA CR-174763, 1984.

52. Gruber, R.P.: Resistojet Control and Power for High Frequency ac Buses. AIAA Paper 87-0994, May 1987 (also NASA TM-89860).

53. Morren, W.E.; and Stone, J.R.: Development of a Liquid-Fed Water Resistojet. AIAA Paper 88-3288, July 1988 (also NASA TM-100927).

54. Manzella, D.H. et al.: An Experimental Investigation of the Effect of Test-Cell Pressure on the Performance of Resistojets. AIAA Paper 88-3286, July 1988.

55. Barr, F.A.; and Page, R.J.: Slip Casting and Extruding Shapes of Rhenium with Metal Oxide Additives. NASA CR-180851, 1987.

56. Morren, W.E.; Whalen, M.V.; and Sovey, J.S.: Performance and Endurance Tests of a Multipropellant Resistojet for Space Station Auxiliary Propulsion. AIAA Paper 86-1435, June 1986 (also NASA TM-87278).

57. Morren, W.E. et al.: Preliminary Performance Characterizations of and Engineering Model Multipropellant Resistojet for Space Station Application. AIAA Paper 87-2120, June 1987 (also NASA TM-100113). 
58. Heckert, B.J.: Space Station Resistojet System Requirements and Interface Definition Study. (RI/RD 87-109, Rockwell International Corp; NASA Contract NAS3-24658), NASA CR-179581, 1987.

59. Pugmire, T.K. et al: A 10,000 Hour Life Multipropellant Engine for Space Station Applications. AIAA Paper 87-1403, June 1987.

60. Tacina, R.R.: Conceptual Design and Integration of a Space Station Resistojet Propulsion Assembly. AIAA Paper 87-1860, June 1987.

61. Zana, L.M. et al.: An Analytical and Experimental Investigation of Resistojet Plumes. AIAA Paper 87-0399, Jan. 1987 (also NASA TM-88852).

62. Louviere, A.J. et al.: Water-Propellant Resistojets for Man-Tended Platforms. NASA TM-100110 (also IAF Paper 87-259).

63. Morren, W.E.; and Sovey, J.S.: 2000-Hour Cyclic Endurance Test of a Laboratory Model Multipropellant Resistojet. AIAA Paper 87-0993, May 1987 (also NASA TM-89854).

64. Whalen, M.V.; and Nathal, M.V.: Compatibility of Dispersion-Strengthened Platinum with Resistojet Propellants. NASA TP-2765, 1987.

65. Bader, C.H.: Potential Propellant Storage and Feed Systems for Space Station Resistojet Propulsion Options. NASA CR-179457, 1987.

66. Whalen, M.V.; Grisnik, S.P.; and Sovey, J.S.: Compatibility Experiments of Facilities, Materials, and Propellants for Electrothermal Thrusters. 1985 JANNAF Propulsion Meeting, Vol. I, K.L. Strange, ed., CPIA-PUBL-425, Chemical Propulsion Information Agency, Laurel, MD, 1985, pp. 475-484.

\section{$\underline{\text { Arcjet }}$}

67. Curran, F.M.; Hardy T.L.; and Haag, T.W.: A Low Power Arcjet Cyclic Lifetest. NASA TM-100233, 1987.
68. Knowles, S.C. et al.: Low Power Hydrazine Arcjets: A System Description for Near-Term Applications. 1986 JANNAF Propulsion Meeting, Vol. 1, K.L. Strange and D.S. Eggleston, eds., CPIA-PUBL-455-VOL-1, Chemical Propulsion Information Agency, Laurel, MD, 1986, pp. 399-408.

69. Pivirotto, T.J.; and King, D.Q.: Thermal Arcjet Technology for Space Propulsion. 1985 JANNAF Propulsion Meeting, Vol. 1, K.L. Strange, ed., CPIA-PUBL-425, 1985, pp. 485-494.

70. Knowles, S.C.: Arcjet Thruster Research and Technology. (REPT-87-R-1175, Rocket Research Corp.; NASA Contract NAS3-24631), NASA CR-182107, 1987.

71. Makel, D.B.: Arcjet Thruster Research and Technology. (RPT/BB0642, Aerojet TechSystems Co.; NASA Contract NAS3-24842), NASA CR-180865, 1988.

72. Nakanishi, S.: Experimental Performance of a 1-Kilowatt Arcjet Thruster. AIAA Paper 85-2033, Sept. 1985 (also NASA TM-87!31).

73. Curran, F.M.; and Haag, T.W.: An Extended Life and Performance Test of a Low-Power Arcjet. AIAA Paper 88-3106, July 1988 (also NASA TM-100942).

74. Cassady, R.J.; Britt, E.J.; and Meya, R.D.: Performance Testing of A Lightweight $30 \mathrm{~kW}$ Arcjet Power Conditioning Unit. AIAA Paper 87-1085, May 1987.

75. Sarmiento, C.J.; and Gruber, R.P.: Low Power Arcjet Thruster Pulse Ignition. AIAA Paper 87-1951, June 1987 (also NASA TM-100123).

76. Carney, L.: Evaluation of the Communications Impact of a Low Power Arcjet Thruster. AIAA Paper 88-3105, July 1988 (also NASA TM-100926). 
77. Ducati, A.C. et al.: 1-kw Arcjet-Engine System Performance Test. J. Spacecraft Rockets, vol. 1, no. 3, May-June 1964, pp. 327-332.

78. Pivirotto, T.J.; King, D.Q.; and Deininger, W.D.: Long Duration Test of a $30-\mathrm{kW}$ Class Thermal Arcjet Engine. AIAA Paper 87-1083, May 1987 (also AIAA Paper 87-1947).

79. Zana, L.M.: Langmuir Probe Surveys of an Arcjet Exhaust. AIAA Paper 87-1950, June 1987 (also NASA TM-89924).

80. Carney, L.M.: An Experimental Investigation of an Arcjet Thruster Exhaust Using Langmuir Probes. NASA TM-100258, 1988.

81. Simon, M.A. et al.: Low Power Arcjet Life Issues. AIAA Paper 87-1059, May 1987.

82. Knowles, S.C. et al.: Performance Characterization of a Low Power Hydrazine Arcjet. AIAA Paper 87-1057, May 1987.

83. Hardy, T.L.; and Curran, F.M.: Low Power dc Arcjet Operation with Hydrogen/Nitrogen/ Ammonia Mixtures. AIAA Paper 87-1948, June 1987 (also NASA TM-89876).

84. Haag, T.W.; and Curran, F.M: Arcjet Starting Reliability: A Multistart Test on Hydrogen/ Nitrogen Mixtures. AIAA Paper 87-1061, May 1987 (also TM-89867).

85. Stone, J.R.; and Huston, E.S.: The NASA/USAF Arcjet Research and Technology Program. AIAA Paper 87-1946, June 1987 (also NASA TM-100112).

86. Curran, F.M.; and Nakanishi, S.: Low Power dc Arcjet Operations with Hydrogen/Nitrogen Propellant Mixtures. AIAA Paper 86-1505, June 1986 (also NASA TM-87279).

87. Gruber, R.P.: Power Electronics for a 1-Kilowatt Arcjet Thruster. AIAA Paper 86-1507, June 1986 (also NASA TM-87340).

88. Burton, R.L. et al.: Investigation of a Repetitive Pulsed Electrothermal Thruster. (GTD86-5,
GT-Devices; NASA Contract NAS3-24636), NASA CR-179464, 1986.

89. Wallner, L.E.; and Czika, J., Jr.: Arc-jet Thruster for Space Propulsion. NASA TN D-2868, 1965.

\section{Microwave-Electrothermal Thruster}

90. Hawley, M.C. et al.: A Review of Research and Development on the Microwave-Plasma Electrothermal Rocket. AIAA Paper 87-1011, May 1987.

91. Frasch, L.L.; Griffin, J.M.; and Asmussen, J.: An Analysis of Electromagnetic Coupling and Eigenfrequencies for Microwave Electrothermal Thruster Discharges. AIAA Paper 87-1012, May 1987.

92. Morin, T.J.; and Hawley, M.C.: The Efficacy of Heating Low-Pressure $\mathrm{H}_{2}$ in a Microwave Discharge. Plasma Chemistry and Plasma Processing, vol. 7, no. 2, June 1987, pp. 181-199.

93. Filpus, J.W.; and Hawley, M.C.: "A Computer Model for the Recombination Zone of a Microwave-Plasma Electrothermal Rocket," AIAA-87-1014.

94. Pollard, J.E.; Lichtin, D.A.; and Cohen, R.B.: RF Discharge Electrothermal Propulsion: Results from a Lab-Scale Thruster. AIAA Paper 87-2124, June 1987.

95. Whitehair, S.; Asmussen, J.; and Nakaubyi, S.: Microwave Electrothermal Thruster Performance in Helium Gas. J. Propulsion, vol. 3, no. 2, Mar.-Apr. 1987, pp. 136-144.

96. Sercel, J.C.: Electron-Cyclotron-Resonance (ECR) Plasma Thruster Research. AIAA Paper 88-2916, July 1988.

Ion Thruster

97. Jones, S.G.; Staskus J.V.; and Byers, D.G.: Preliminary Results of SERT II Spacecraft Potential Measurements Using Hot Wire Emmissive Probes. AIAA Paper 70-1127, Aug. 1970. 
98. Galecki, D.L.; and Patterson, M.J.: Nuclear Powered Mars Cargo Transport Mission. AIAA Paper 87-1903, June 1987 (also NASA TM-100109).

99. Shimada, S. et al.: Ion Engine System for North-South Station Keeping of Engineering Test Satellite VI. AIAA Paper 87-1005, May 1987.

100. Byers, D.C.; and Staggs, J.F.: SERT II: Thruster System Ground Testing. J. Spacecraft Rockets, vol. 7, no. 1, Jan. 1970, pp. 7-14.

101. Kerslake, W.R. et al.: Flight and Ground Performance of the SERT II Thruster. AIAA Paper 70-1125, Aug. 1970.

102. Mahoney, S.P.; and Merkatu, M.M.: Nuclear Powered Ion Engine Orbit Transfer Vehicle Design and Operational Effectiveness. AIAA Paper 86-1391, June 1986.

103. Nock, K.T. et al.: Lunar Get Away Special (GAS) Spacecraft. AIAA Paper 87-1051, May 1987.

104. Kitamura, S. et al:: ETS-III Ion Engine Flight Operations in the Extended Mission Period. J. Propulsion Power, vol. 2, no. 6, Nov.-Dec. 1986, pp. 513-520.

105. Brophy, J.R.; and Wilbur, P.J.: Simple Performance Model for Ring and Line Cusp Ion Thrusters. AIAA. J., vol. 23, no. 11, Nov. 1985, pp. 1731-1736.

106. Wilbur, P.J.; and Han, J.: Constrained Sheath Optics for High Thrust Density, Low Specific Impulse Ion Thrusters. AIAA Paper 87-1073, May 1987.

107. Garner, C.E.; Brophy, J.R.; and Aston, G.: The Effects of Gas Mixtures on Ion Engine Erosion and Performance. AIAA Paper 87-1080, May 1987.

108. Aston, G.: A Xenon Ion Propulsion Module for Enhanced Spacecraft Capability. AIAA Paper 86-1393, June 1986.
109. Matossian, J.N.; and Beattie, J.R.: Plasma Properties in Electron Bombardment Ion Thrusters. AIAA Paper 87-1076, May 1987.

110. Schreib, R.: Utility of Xenon Ion Stationkeeping. AIAA Paper 86-1849, June 1986.

111. Brophy, J.R.; and Garner, C.E.: Tests off High Current Hollow Cathodes for Ion Engines.

AIAA Paper 88-2913, July 1988.

112. Garner, C.E.; Brophy, J.R.; and Press, L.C.: "Ion Propulsion System Design and Throttling Strategies for Planetary Missions," AIAA-88-2910.

113. Aston, G. et al.: Operating Characteristics of a $10 \mathrm{~kW}$ Xenon Ion Propulsion Module. AIAA Paper 87-1006, May 1987.

114. Aston, G.; and Brophy, J.R.: Ion Accelerator System Mounting Design and Operating Charac-

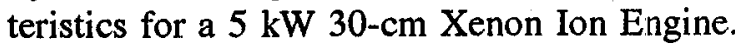
AIAA Paper 87-1075, May 1987.

115. Beattie, J.R.; Matossian, J.N.; and Robson, R.R.: Status of Xenon Ion Propulsion Technology. J. Propulsion Power, vol. 6, no. 2, Mar.-Apr. 1990, pp. 145-150.

116. Patterson, M.J.; and Rawlin, V.K.: Performance of 10-kW Class Xenon Ion Thrusters. AIAA Paper 88-2914, July 1988 (also NASA TM-101292).

117. Rawlin, V.K.: Internal Erosion Rates of a 10-kW Xenon Ion Thruster. AIAA Paper 88-2912, July 1988 (also NASA TM-100954).

118. Brophy, J.R.; and Wilbur, P.J.: An Experimental Investigation of Cusped Magnetic Field Discharge Chambers. AIAA J., vol. 24, no. 1, Jan. 1986, pp. 21-26.

119. Brophy, J.R.; and Wilbur, P.J.: Calculation of Plasma Properties in Ion Sources. AIAA J., vol. 24, no. 9, Sept. 1986, pp. 1519-1523. 
120. Wilbur, P.J.; and Brophy, J.R.: The Effect of Discharge Chamber Wall Temperature on Ion Thruster Performance. AIAA J., vol. 24, no. 2, Febb. 1986, pp. 278-283.

121. Byers, D.C.; and Banks, B.A: Survey of Electron-Bombardment Thruster Research. IEEE Trans. Plasma Sci., vol. PS-2, June 1973, pp. $1-9$.

122. Rawlin, V.K.; Banks, B.A.; and Byers, D.C.: Design, Fabrication, and Operation of Dished Accelerator Grids on a 30-cm Ion Thruster. AIAA Paper 72-486, Apr. 1972 (also NASA TM X-68013).

123. Byers, D.C.; and Reader, P.D.: ElectronBombardment Ion Sources Operation Using Various Gases. 11 th Symposium on Electron, Ion, and Laser Beam Technology, R.F.M. Thormley, ed., IEEE, 1971, pp. 615-622 (also NASA

TM X-67831).

124. Byers, D.C.: A Review of Electron Bombardment Thruster System/Spacecraft Field and Particle Interfaces. AIAA Paper 78-677, Apr. 1978 (also NASA TM-78850),

\section{Magnetoplasmadynamic Thruster}

125. Kuriki, K. et al.: Space Experiment with Particle Accelerators (SEPAC) Performed in SpaceLab First. AIAA Paper 85-1996, Sept. 1985.

126. Brill, Y.; Eisner, A.; and Osborn, L.: The Flight Application of a Pulsed Plasma Microthruster; The NOVA Satellite. AlAA Paper 82-1956, 1982.

127. King, D.Q.; and Brophy, J.R.: Design and Operation of a $100 \mathrm{~kW}$, Subscale MPD Engine.

AIAA Paper 87-1020, May 1987.

128. Meyers, R.M. et al.: Cathode Phenomena in a Low Power, Steady State MPD Thruster. AIAA Paper 88-3206, July 1988.
129. Gilland, J.H.; Kelly, A.J.; and Jahn, R.G.: MPD Thruster Scaling. AIAA Paper 87-0997, May 1987.

130. Coomes, E.P. et al: PEGASUS: A MultiMegawatt Nuclear Electric Propulsion System. Manned Mars Mission, Working Group Papers, Vol. 2, Sect. 5, App., M.B. Duke and P.W. Keaton, eds., NASA TM-89321, Vol. 2, 1986, pp. 769-786.

131. Polk, J.E.; Kelly, A.J.; and John, R.G.: MPD Thruster Erosion Research. AIAA Paper 87-0999, May 1987.

132. Merfeid, D.J.; Kelly, A.J.; and Jahn, R.G.: MPD Thruster Performance: Propellant Distribution and Species Effects. J. Propulsion Power, vol. 2, no. 4., July-Aug. 1986, pp. 317-332.

133. Sovey, J.S.; and Mantenieks, M.A.: Performance and Lifetime Assessment of MPD Arc Thruster Technology. AIAA Paper 88-3211, July 1988 (also NASA TM-101293).

134. Choueiri, E.Y.; Kelly, A.J.; and Jahn, R.G.: MPD Thruster Plasma Instability Studies. AIAA Paper 87-1067, May 1987.

135. Myers, R.; Kelly, A.J.; and Jahn, R.G.: Electrothermal-Electromagnetic Hybrid Thruster Research. AIAA Paper 87-1018, May 1987.

136. King, D.Q.; and Sercel, J.C.: A Review of the Multi-Megawatt MPD Thruster and Current Mission Applications. AIAA Paper 86-1437, June 1986.

$\underline{\text { Nuclear }}$

137. Howe, S.D.: Assessment of the Advantages and Feasibility of a Nuclear Rocket for a Manned Mars Mission. Manned Mars Mission, Workshop Group Papers, vol. 2, sect. 5 - appendix, M.B. Duke and P.W. Keaton, eds., NASA TM-89321-VOL-2, 1986, pp. 856-872. 
138. Johnson, P.G.: Beyond Apollo with Nuclear Propulsion. Astronaut. Aeronaut., vol. 2, no. 12, Dec. 1964, pg 22-28.

139. Finger, H.B.: Nuclear Rocketry - Confidence Substantiated. Astronaut. Aeronaut., vol. 3, no. 6, June 1965, pp. 34-35.

140. Jordan, W.Y., Jr.; Harris, R.J.; and Saxton, D.R.: Toward Modular Nuclear-Rocket Systems. Astronaut. Aeronaut., vol. 3, no. 6, June 1965, pp 48-52.

141. Schroeder, R.W.: NERVA - Entering a New Phase. Astronaut. Aeronaut., vol. 6, no. 5, May 1968, pp. 42-53.

142. Corrington, L.C.: The Nuclear Rocket ProgramIts Status and Plans. J. Spacecraft Rockets, vol. 6 , no. 7 , July 1969 , pp. 465-470.

143. Buden, D.: Operational Characteristics of Nuclear Rockets. J. Spacecraft Rockets, vol. 7, no. 7 , July 1970 , pp. 832-836.

144. Altselmer, J.H.; Mader, G.F.; and Stewart, J.J.: Operating Characteristics and Requirements for the NERVA Flight Engine. J. Spacecraft Rockets, vol. 8, no. 7, July 1971, pp. 766-773.

145. Holman, R.R.; and Pierce, B.L.: Development of NERVA Reactor for Space Nuclear Propulsion. AIAA Paper 86-1582, June 1986.

146. Buden, D.: Nuclear Rocket Safety. IAF Paper 87-297, Oct. 1987.
147. Kendall, J.S.; and Latham, T.S.: Summary of Fluid Mechanics and Engine Characteristics Research on the Nuclear Light Bulb Engine Concept. AIAA Paper 70-689, June 1970.

148. McLafferty, G.H.: Gas Core Nuclear Rocket Engine Technology Status. J. of Spacecraft Rockets, vol. 7, no. 12, Dec. 1970, pp. 1391-1396.

149. Latham, T.S.: Summary of the Performance Characteristics of the Nuclear Light Bulb Engine. AIAA Paper 71-642, June 1971.

150. Fishback, L.H.; and Willis, E.A., Jr.: Performance Potential of Gas-Core and Fusion Rockets: A Mission Applications Survey. 2nd Symposium on Uranium Plasmas: Research and Applications, AIAA, 1971, pp. 18-27 (also NASA TM X-67940).

151. Ragsdale, R.G.; and Willis, E.A., Jr.: Gás Core Rocket Reactors-A New Look. AIAA Paper 71-641, June 1971.

152. Ragsdale, R.G.: To Mars in 30 Days by GasCore Nuclear Rocket. Astronaut. Aeronaut., vol. 10, no. 1, Jan. 1972, pp. 65-71.

153. Lezius, D.K. and Thomas, P.D.: "Nondestructive Evaluation of Composite Structures in Space," AL-TR-89-021, July 1989. 


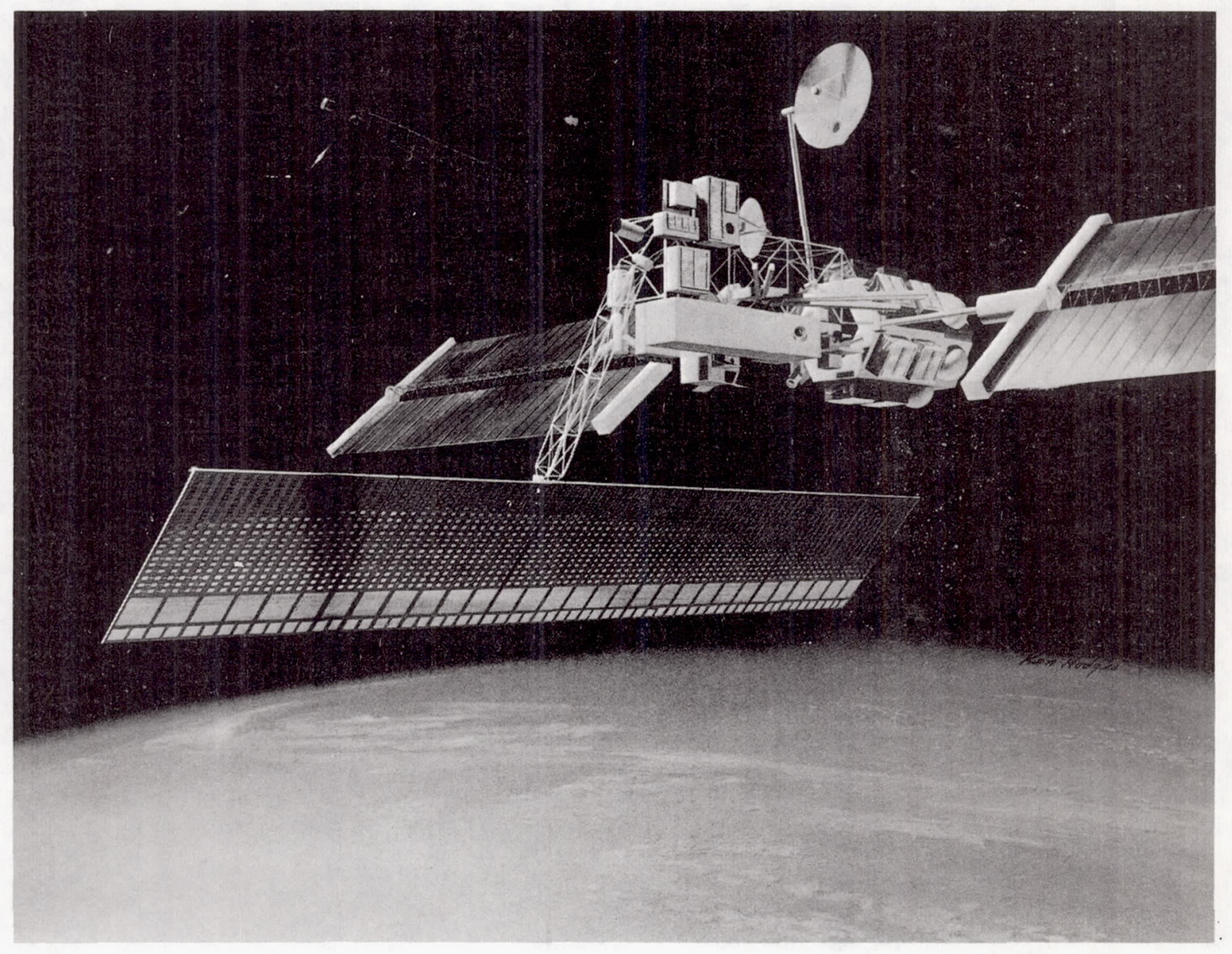

FIGURE 1. - ARTIST'S CONCEPI OF EARTH OBSERVING SYSTEM (EOS) POLAR ORBITING MISSION. 


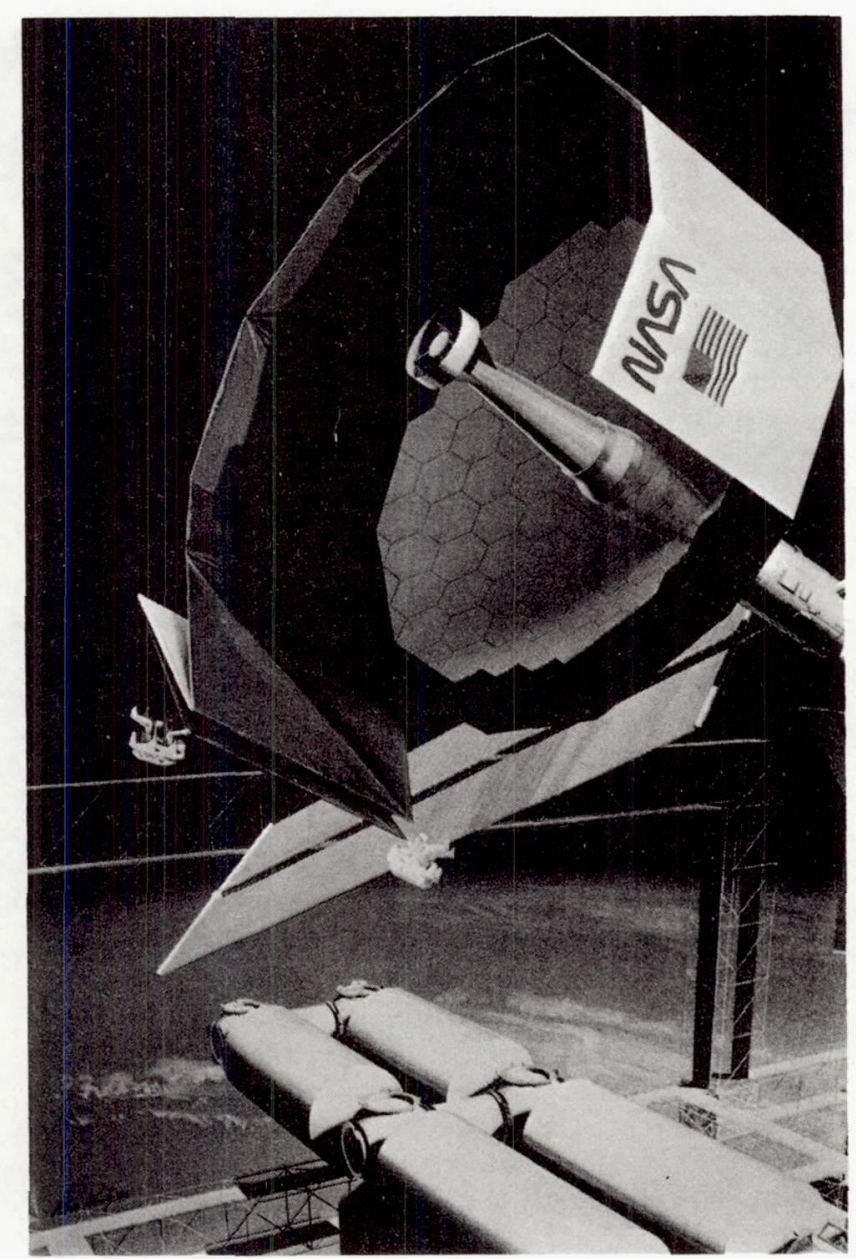

FIGURE 2. - ARTIST'S CONCEPT OF LARGE DEPLOYABLE REFLECTOR. 


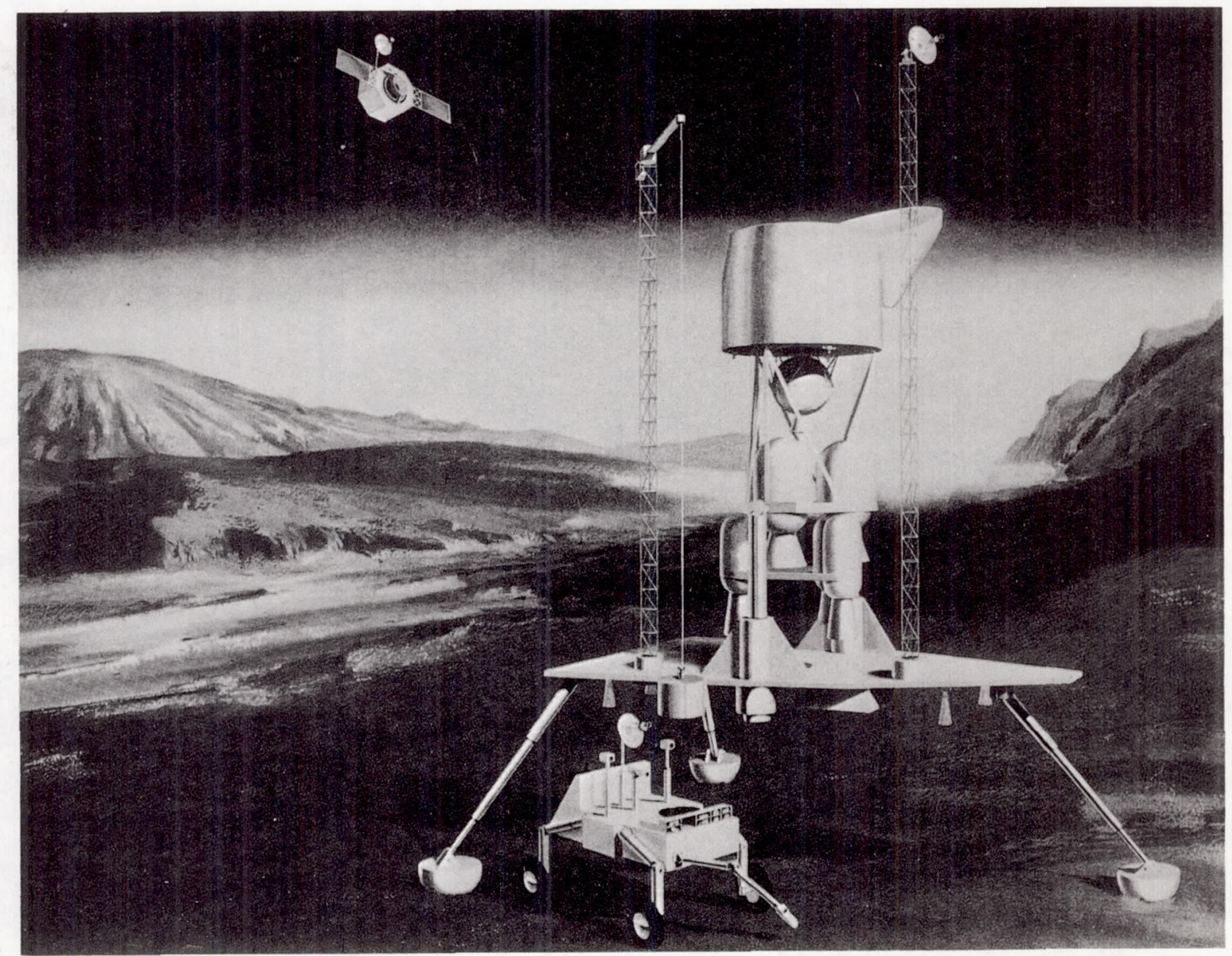

FIGURE 3. - ARTIST'S CONCEPT OF THE LANDER, ROVER, AND COMBINED SAMPLE RETURN SYSTEM AND LAUNCHER ON THE SURFACE OF MARS. 


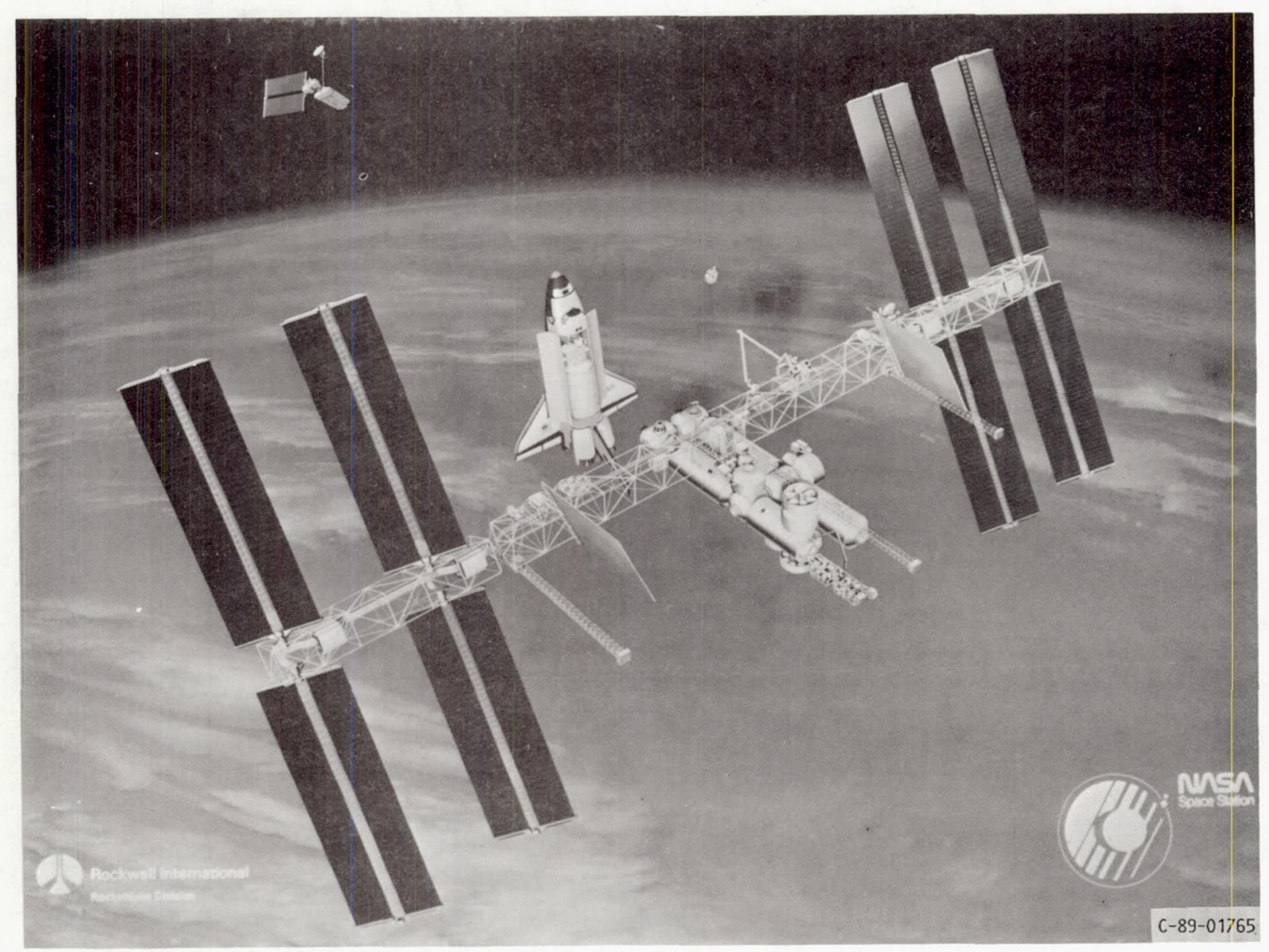

FIGURE 4. - SPACE STATION FREEDOM. 


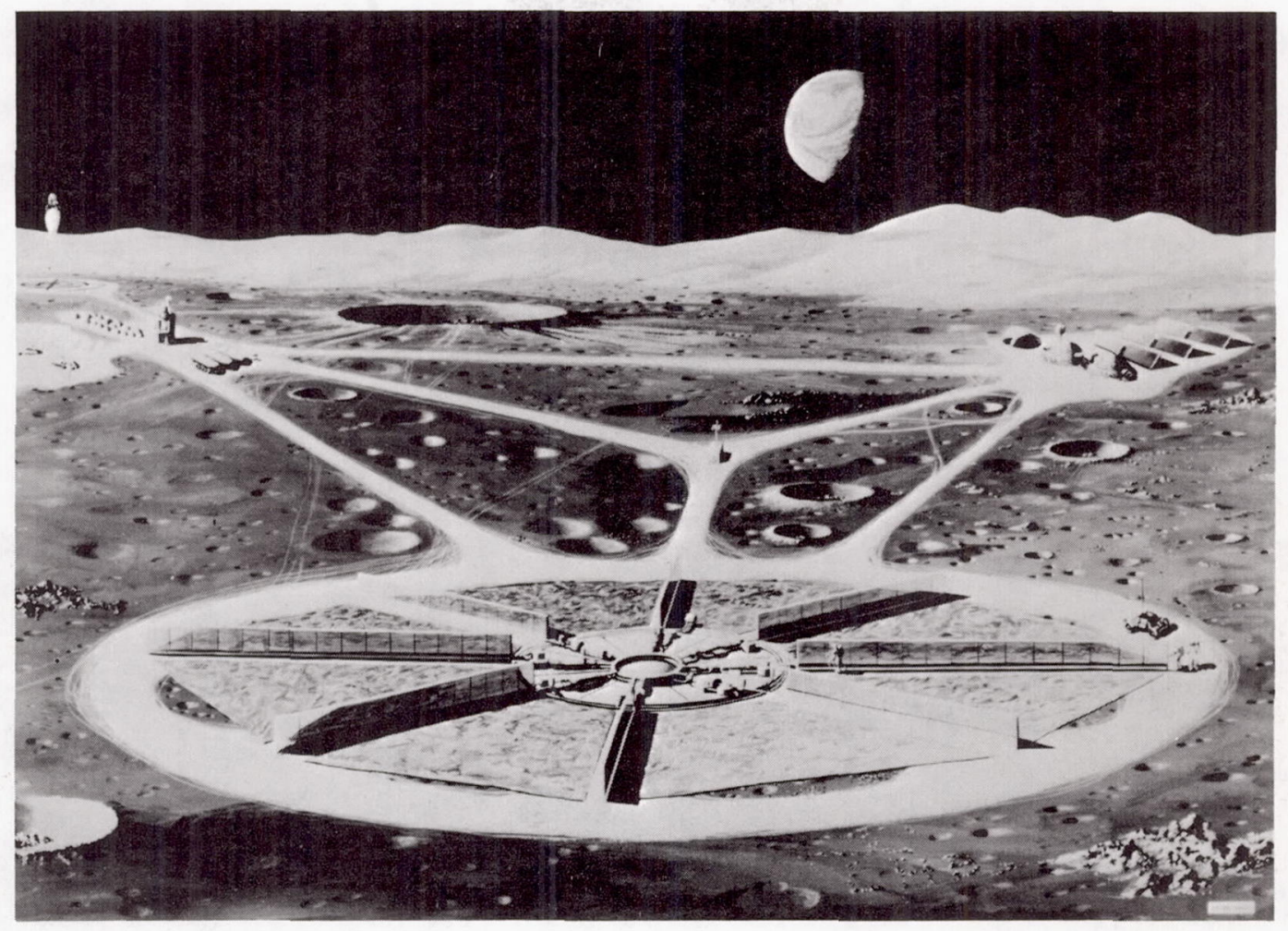

FIGURE 5. - ARIIST'S CONCEPI OF LUNAR BASE.

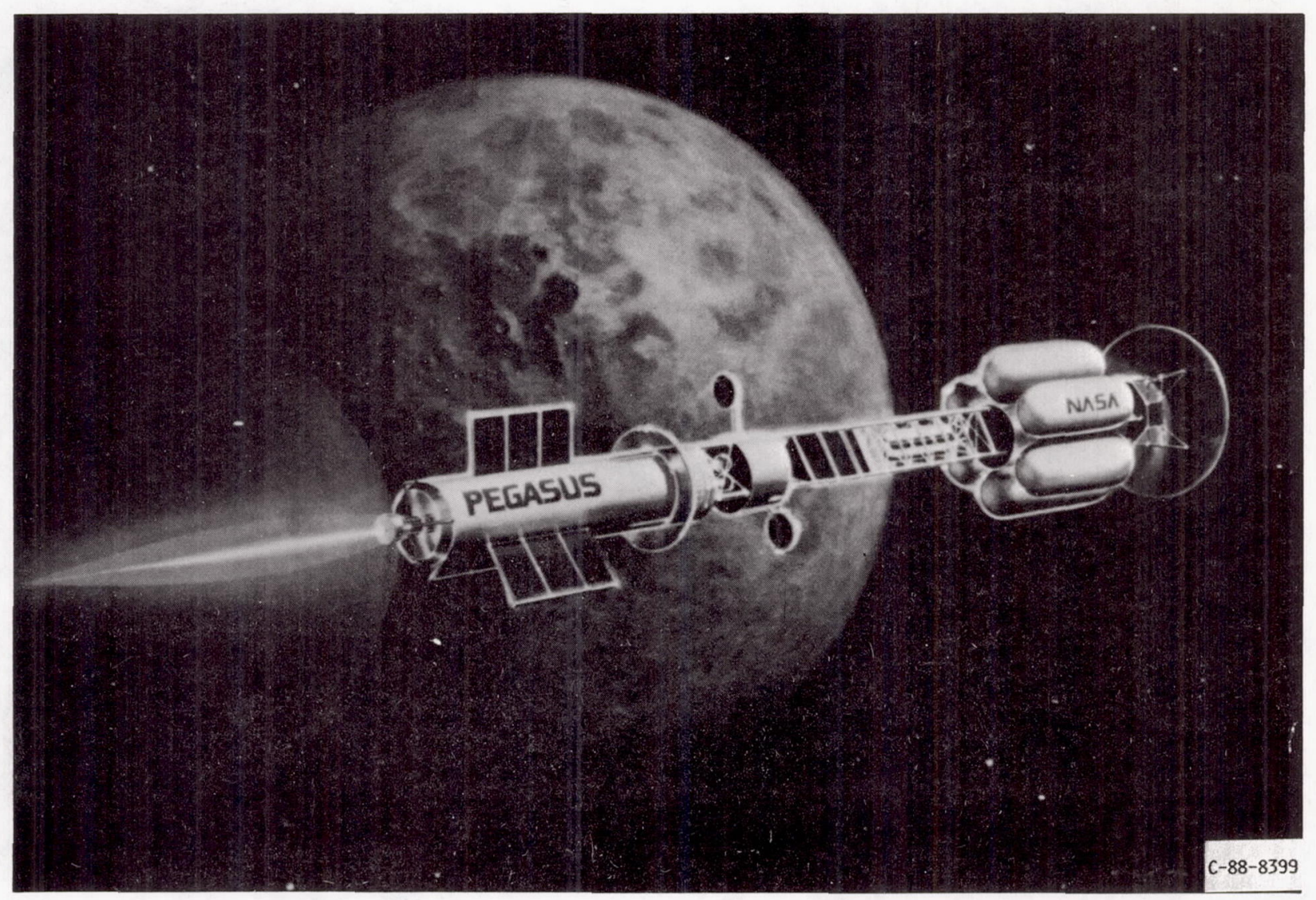

FIGURE 6. - ARTIST'S CONCEPT OF MARS MISSION. 


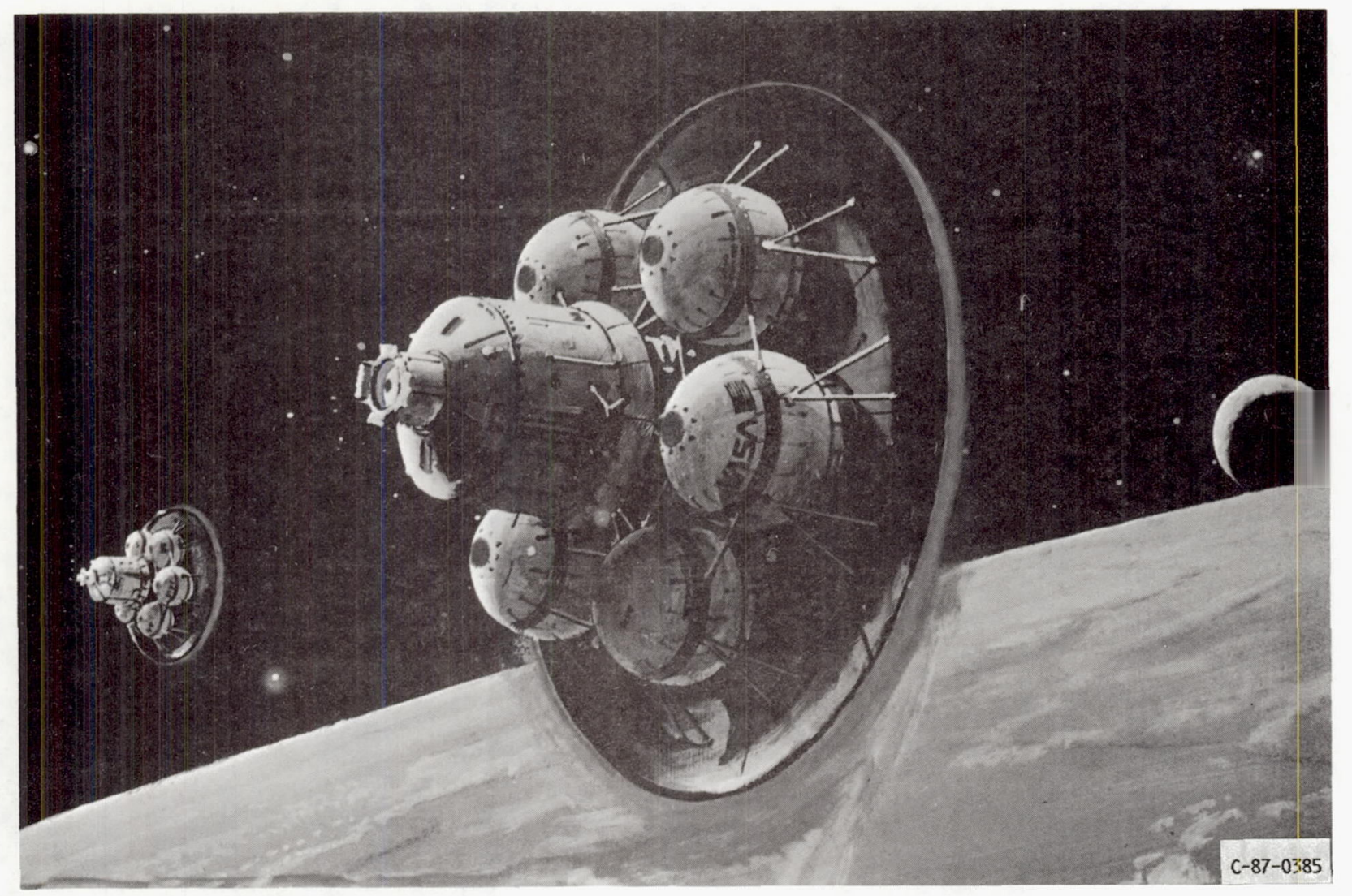

FIGURE 7. - ARTIST'S CONCEPT OF AEROBRAKING VEHICLE. 


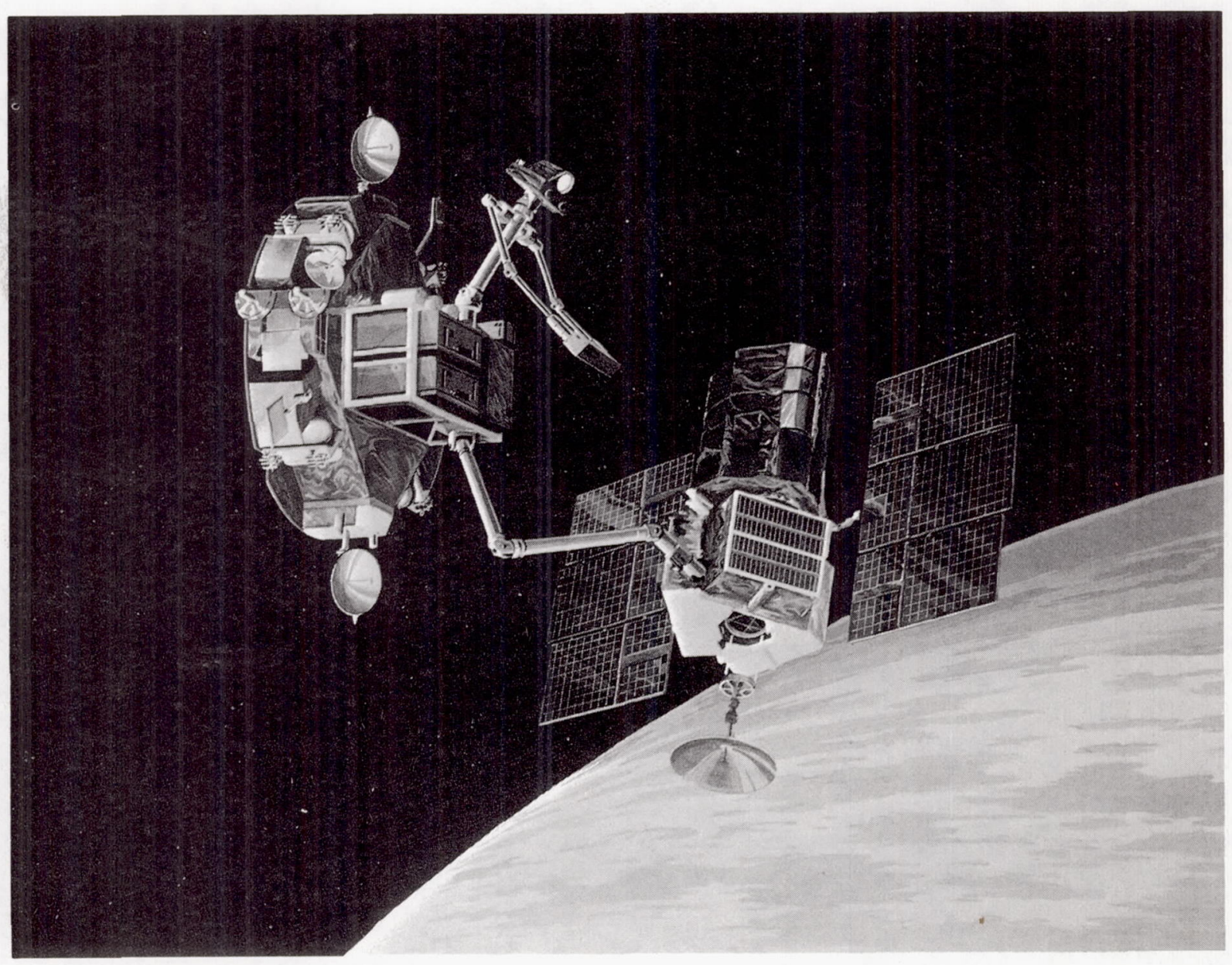

FIGURE 8. - CURRENT SPACE ROBOT CONCEPT ORBITAL MANEUVERING VEHICLE WITH MANIPULATIVE CAPABILITY.

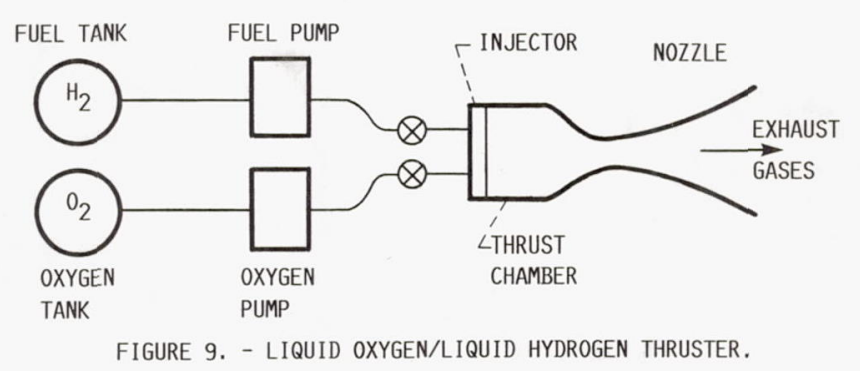




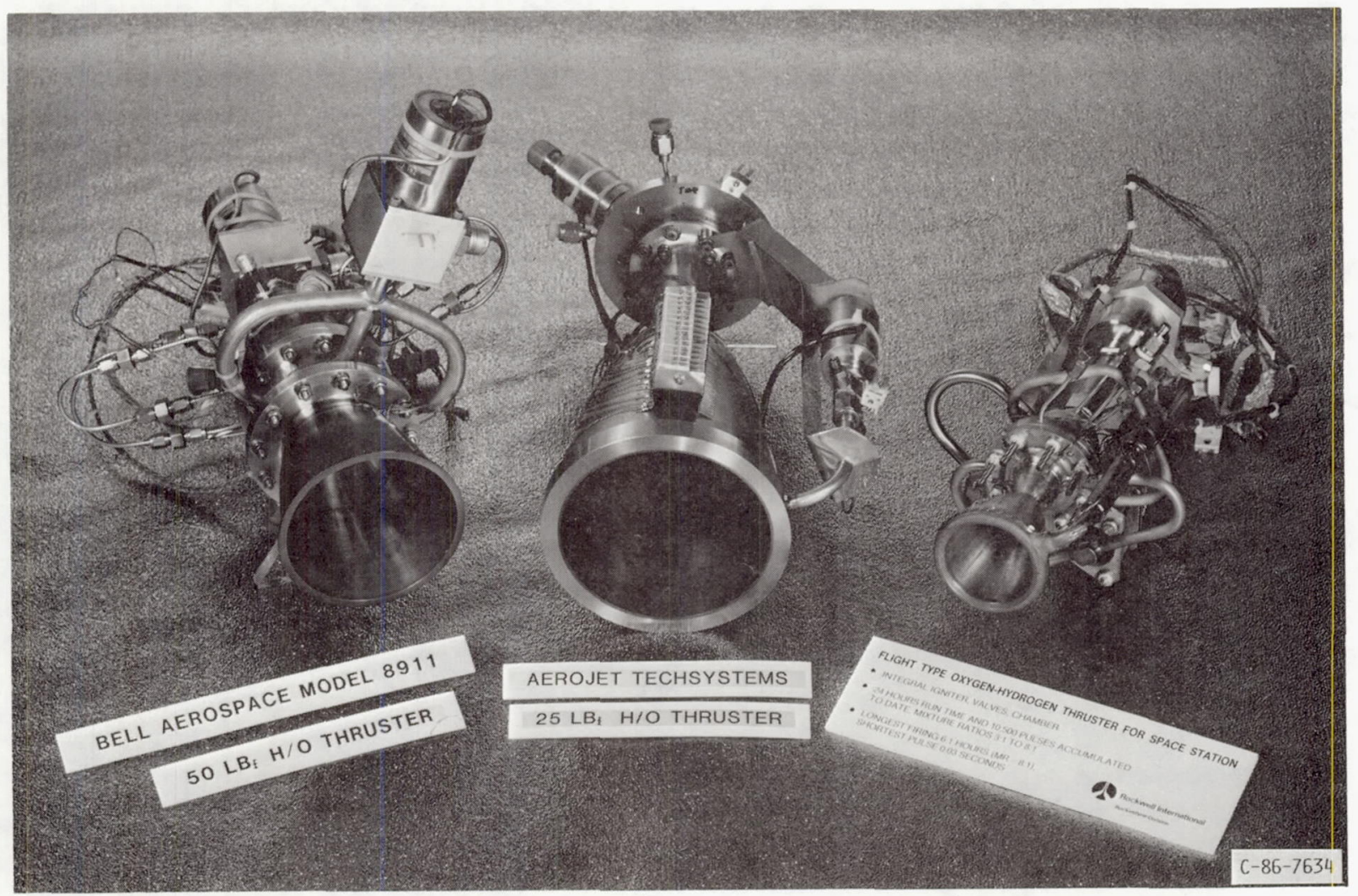

FIGURE 10. - SPACE STATION HYDROGEN/OXYGEN THRUSTERS.

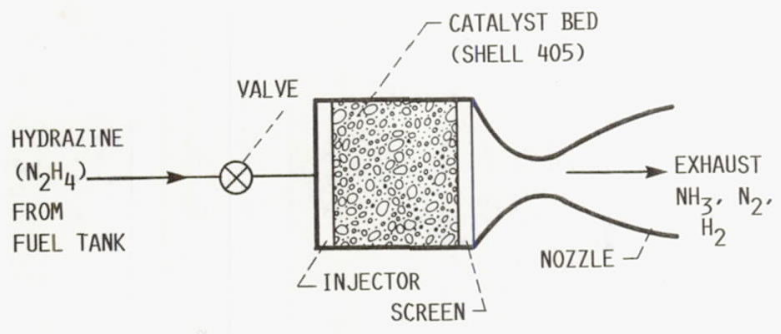

FIGURE 11. - HYDRAZINE THRUSTER.

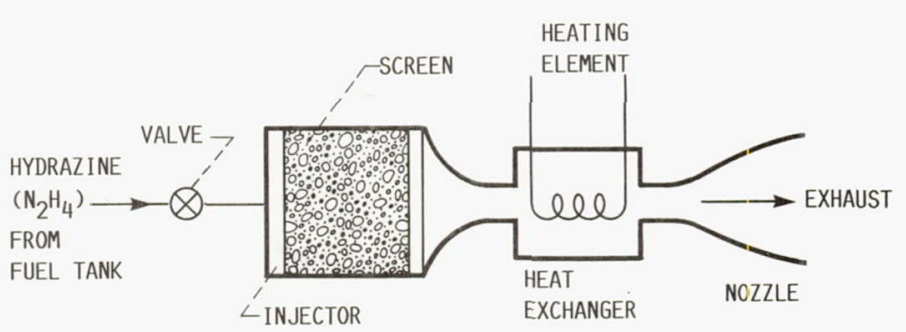

FIGURE 12. - AUGMENTED HYDRAZINE THRUSTER. 

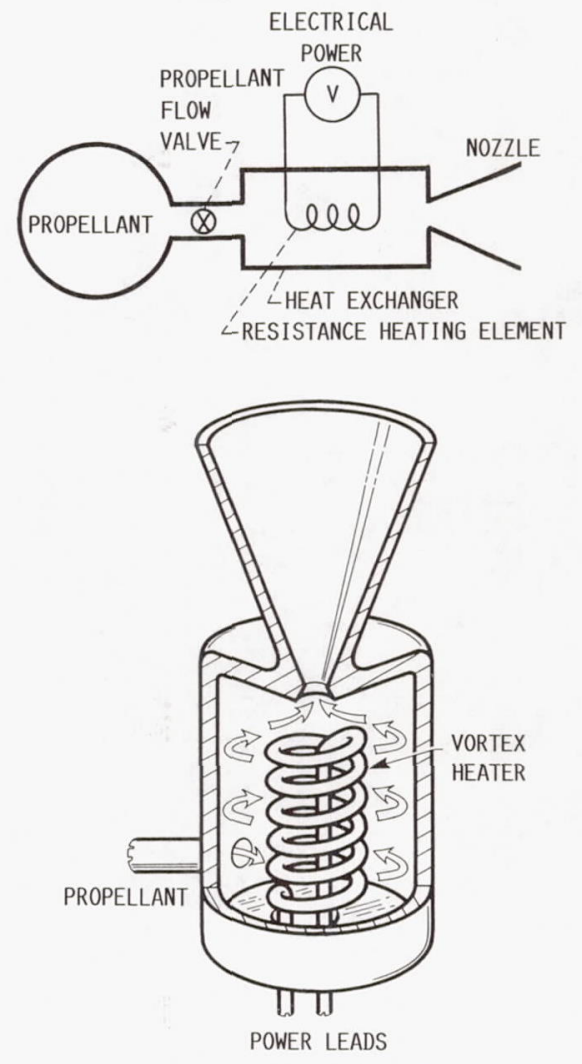

FIGURE 13. - RESISTOJET.
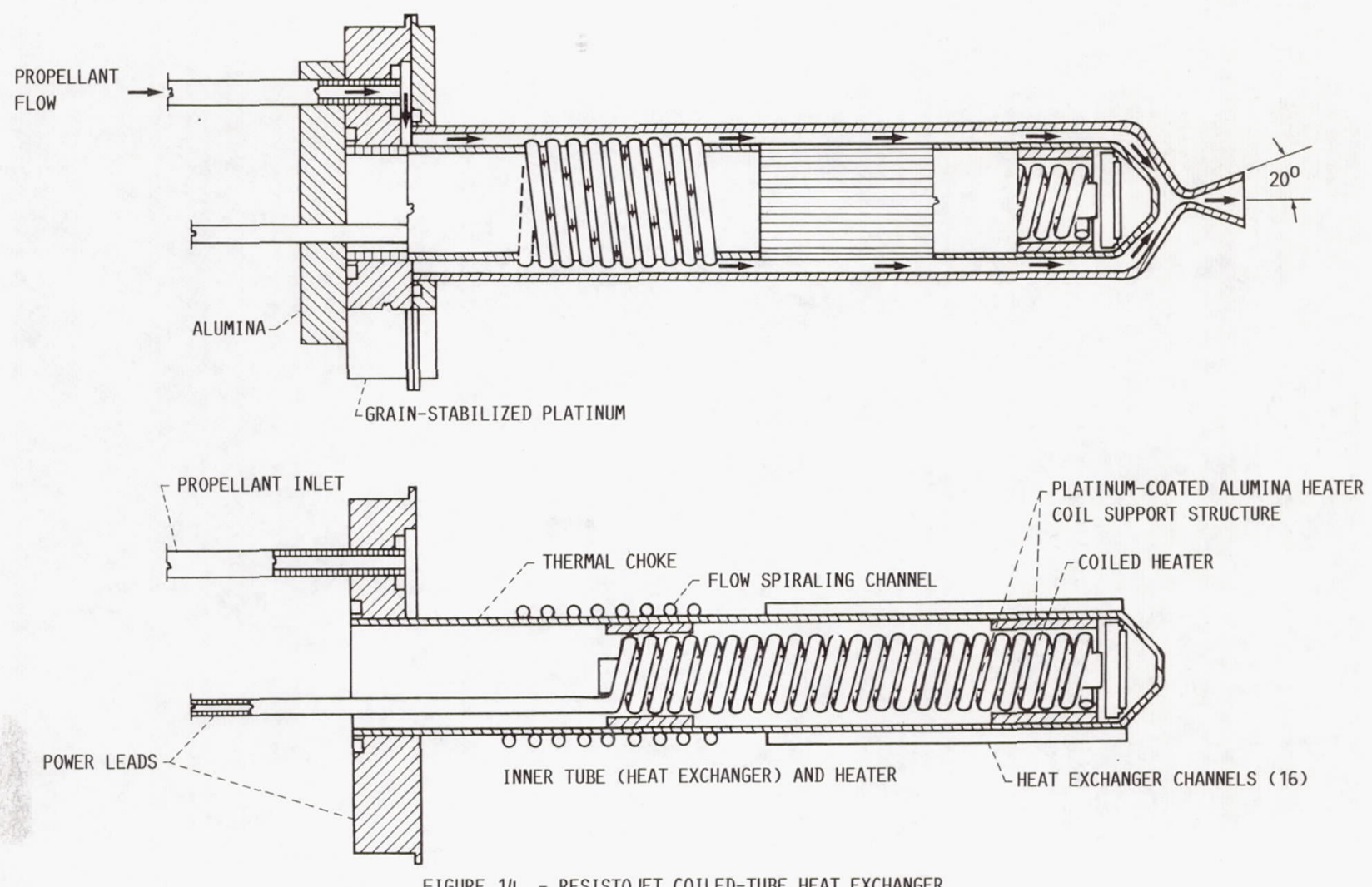

FIgURE 14. - RESISTOJET COILED-TUBE HEAT EXCHANGER. 


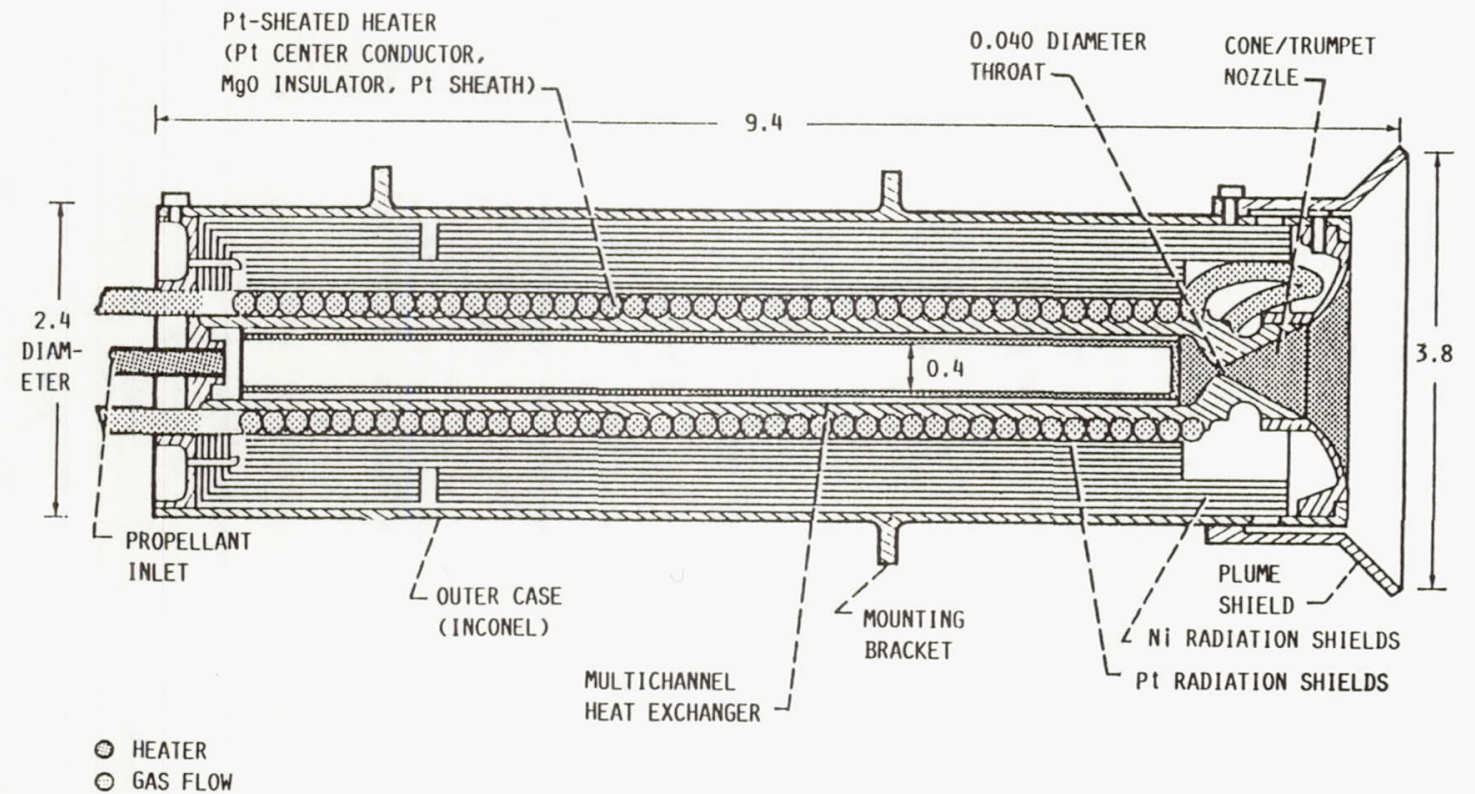

FIGURE 15. - CROSS-SECTION OF RESISTOJET MODEL. ALL DIMENSIONS IN INCHES.

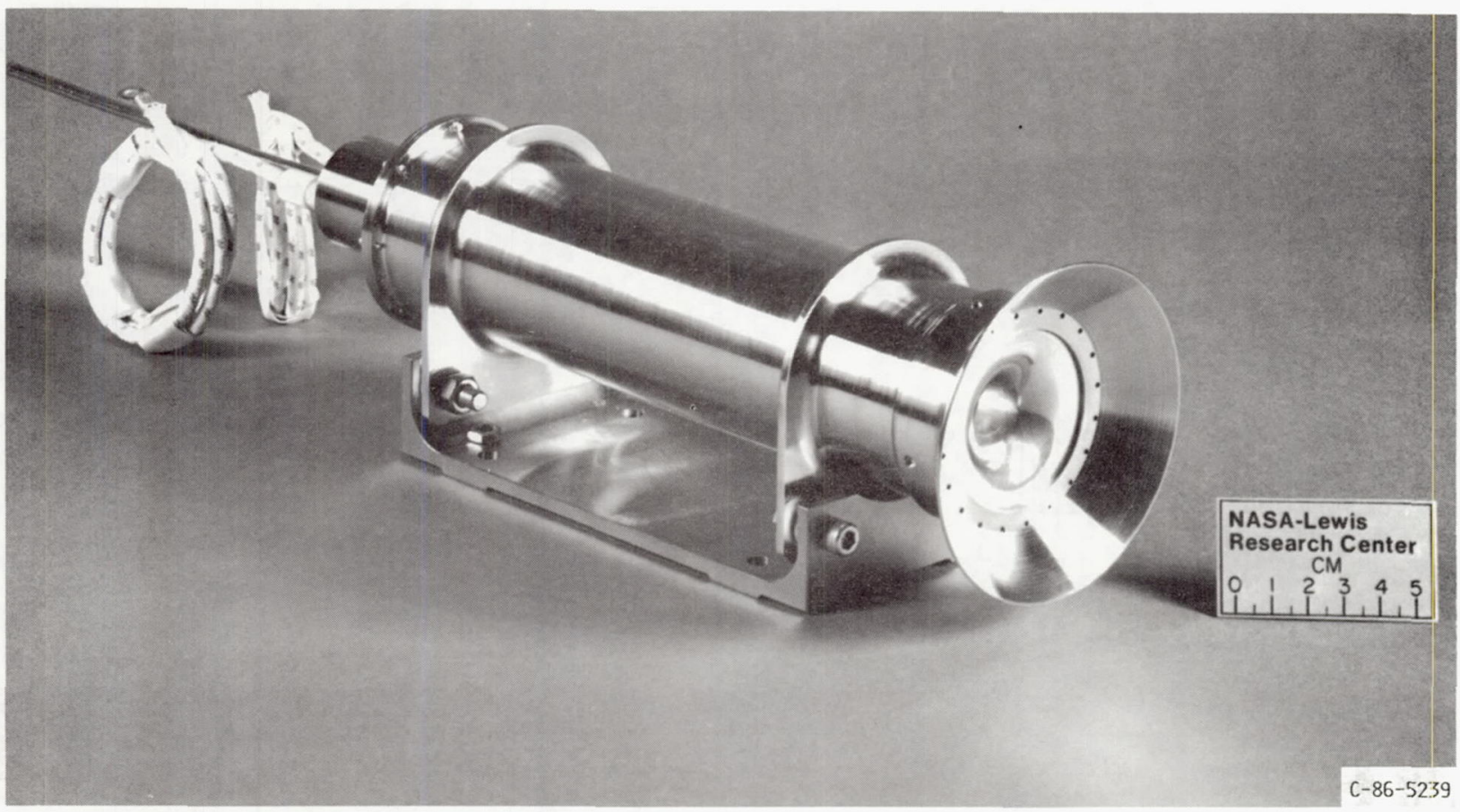

FIGURE 16. - ENGINEERING MODEL OF RESISTOJET. 


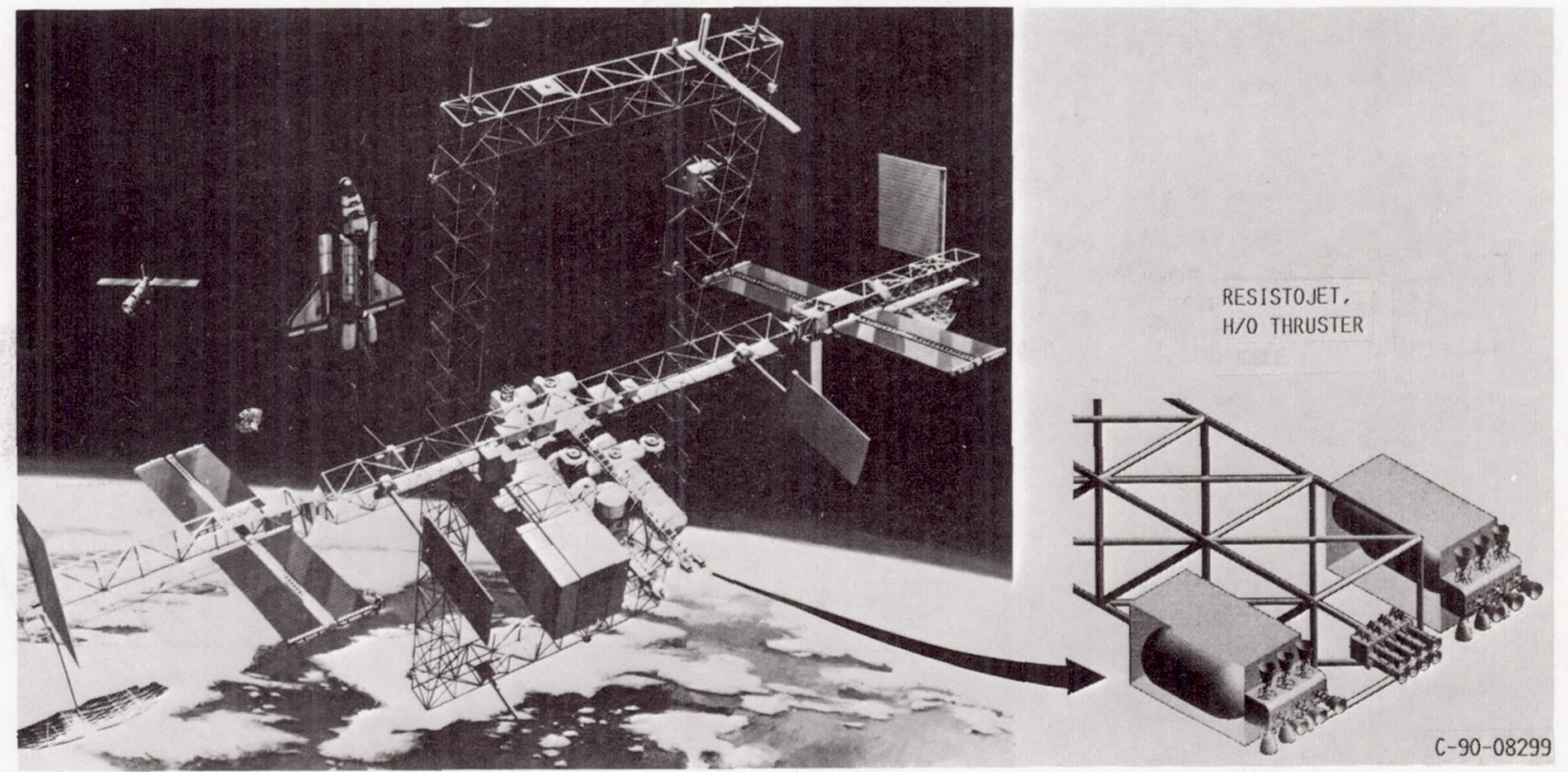

FIGURE 17. - INITIAL OPERATING CONFIGURATION OF RESISTOJET.

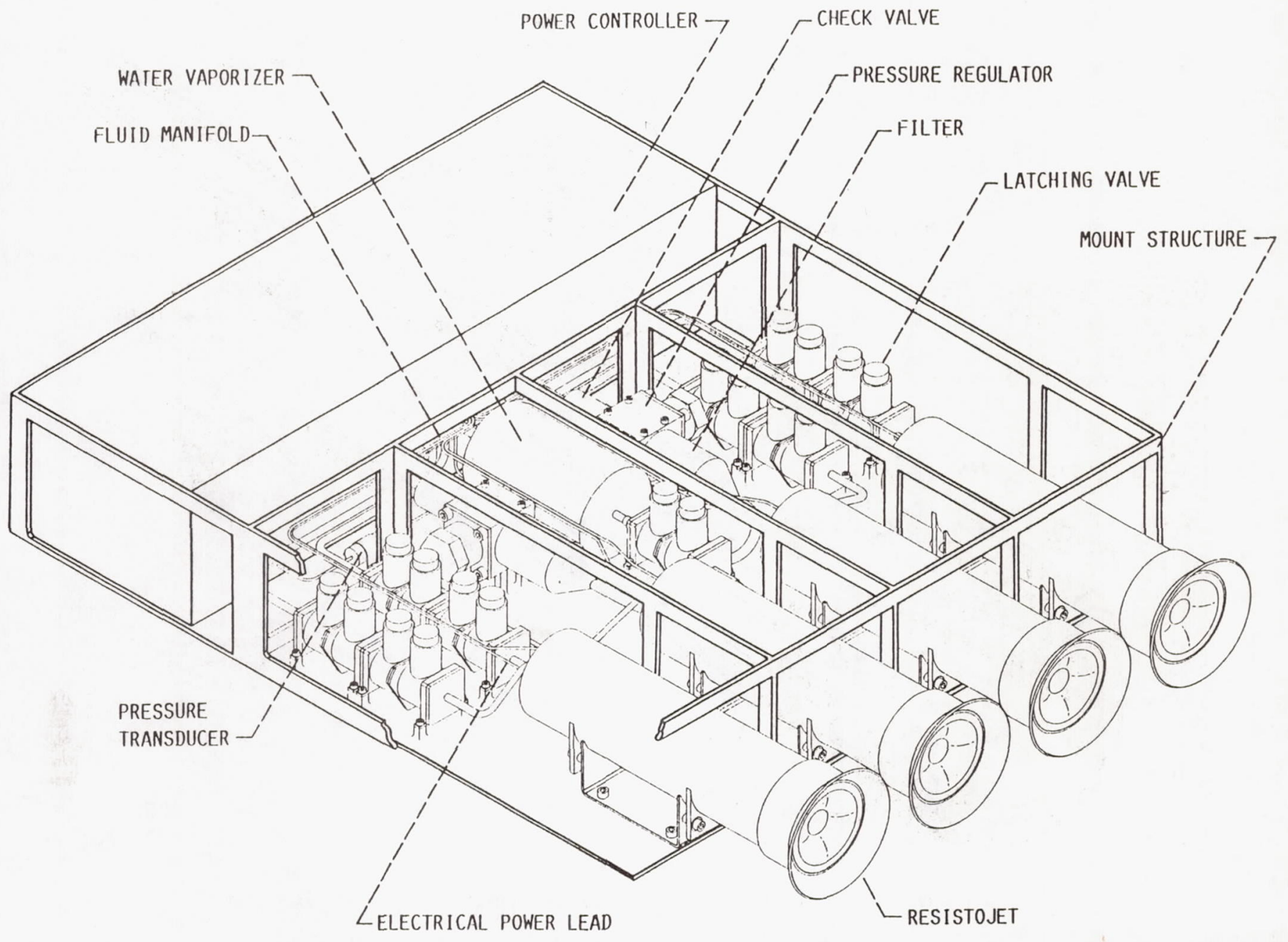

FIGURE 18, - LAYOUT OF RESISTOJET MODULE. 


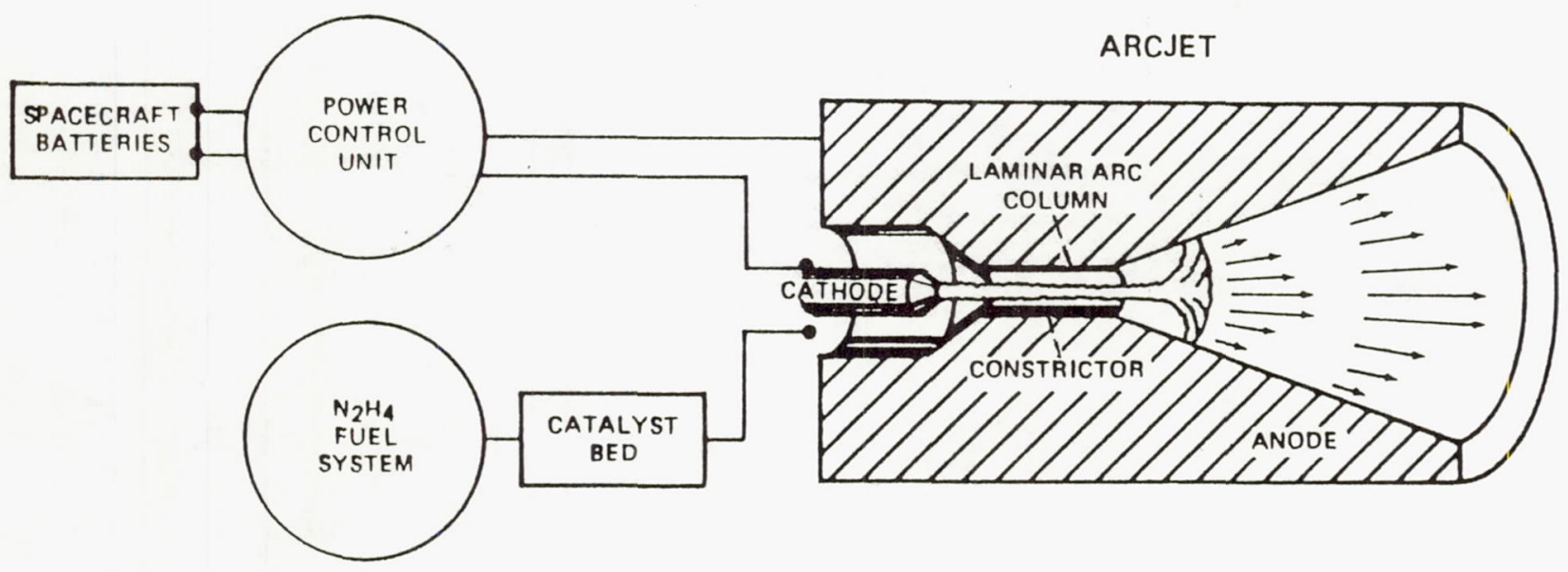

FIGURE 19. - ARC.JET.

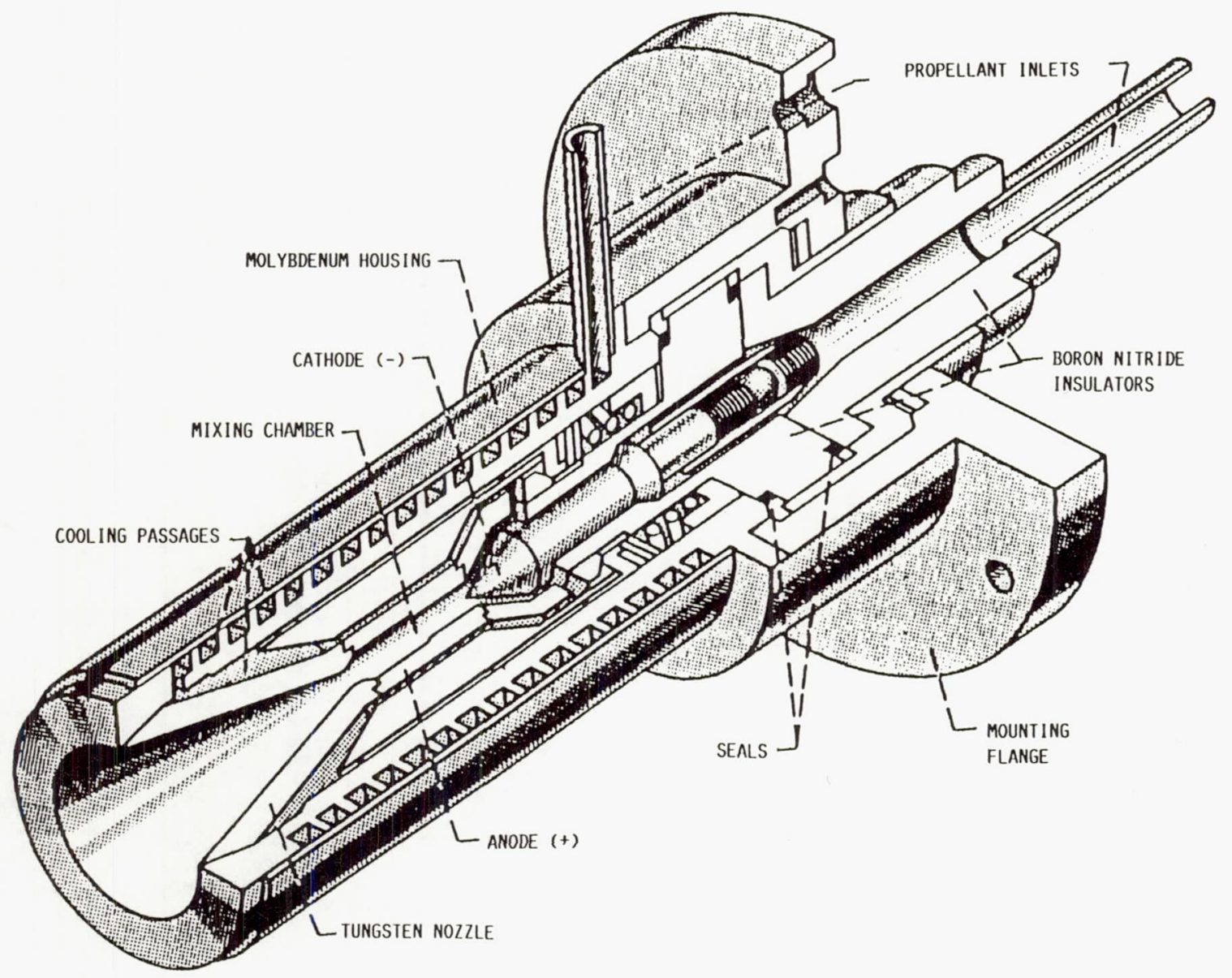

FIGURE 20, - 30-kW THERMAL ARCJET ENGINE DESIGNED BY GIANNINI SCIENIIFIC CORPORATION. 


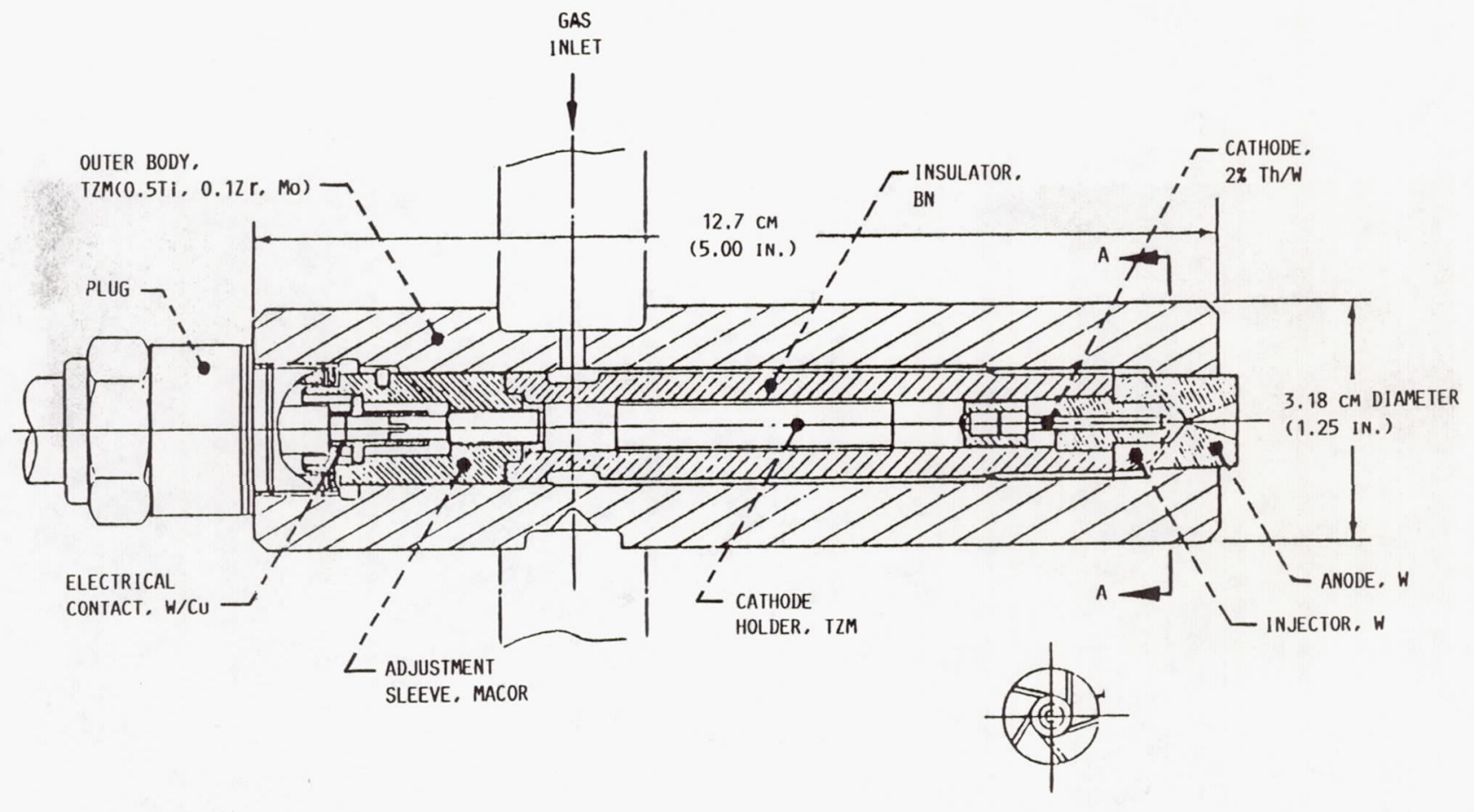

FIGUNi 21. - $\mathrm{N}_{2} \mathrm{H}_{2}$ ARCJET DESIGN.

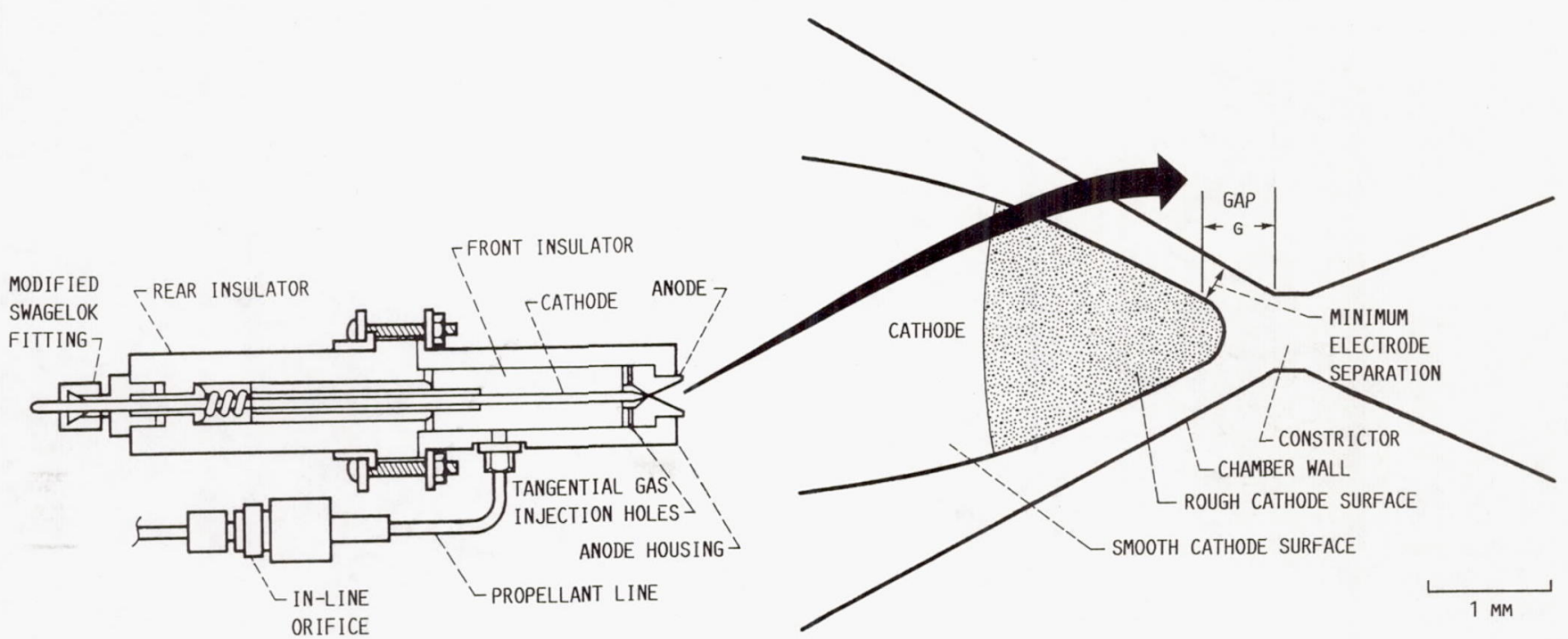

FIGURE 22. - CUTAWAY VIEWS OF ARCJET. 


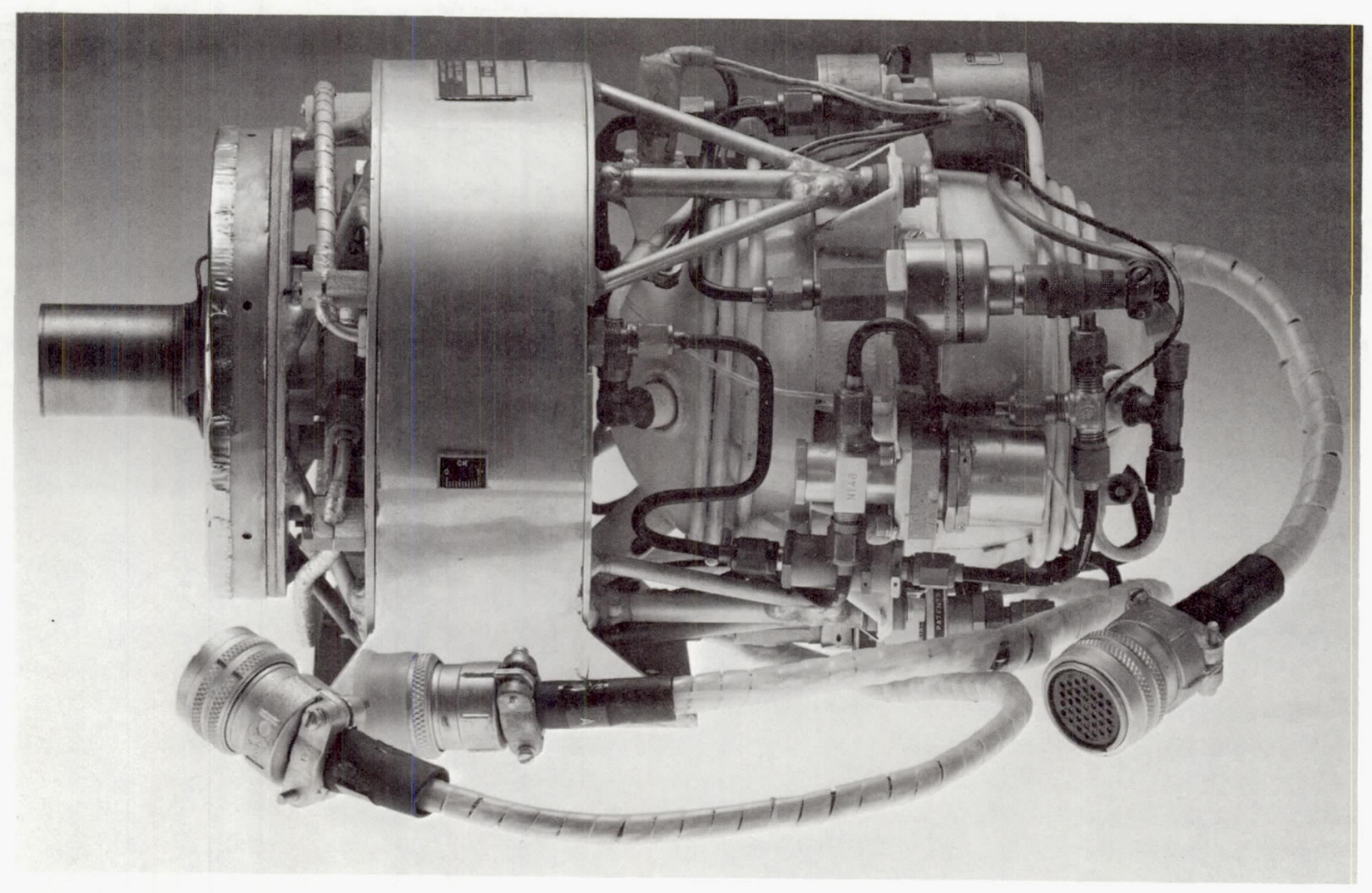

FIGURE 23. - PLASMADYNE 1-kW ARCJET THRUSTER FLIGHT SYSTEM.
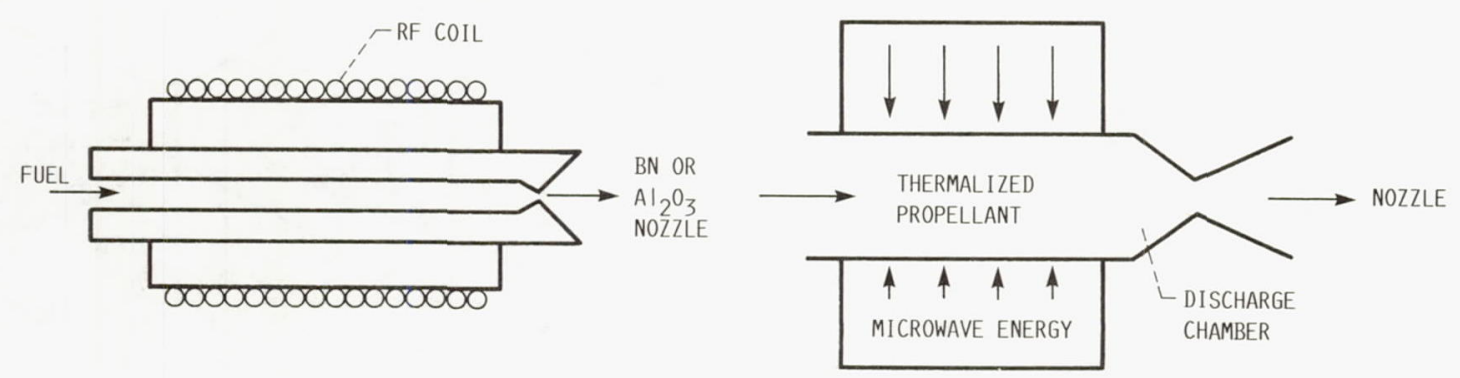

FIGURE 24. - MICROWAVE THRUSTERS. 
NEUTRAL IZER
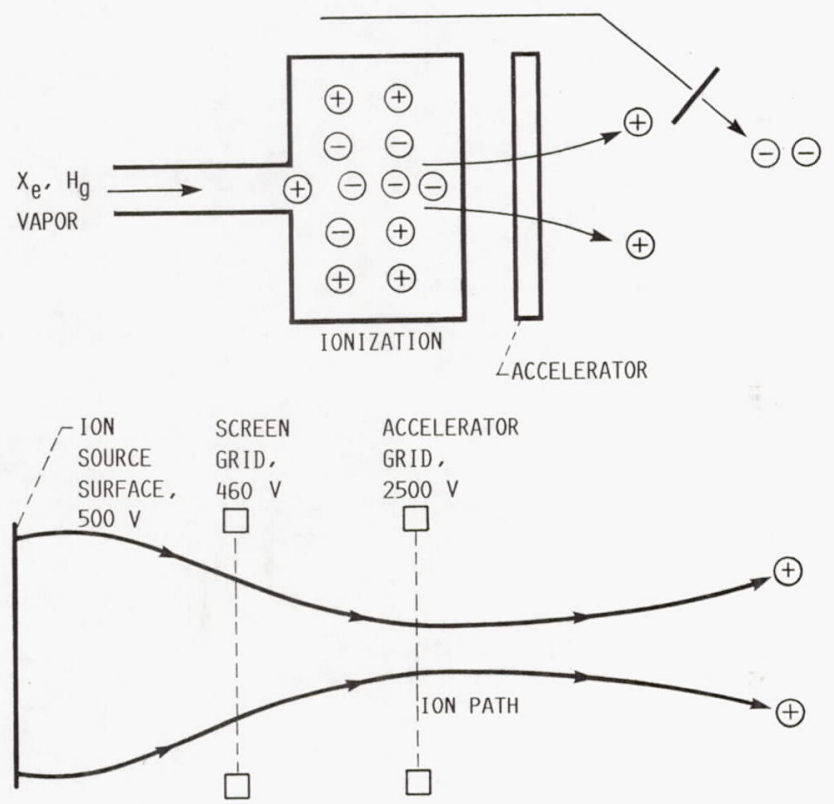

FIGURE 25. - ION THRUSTER.

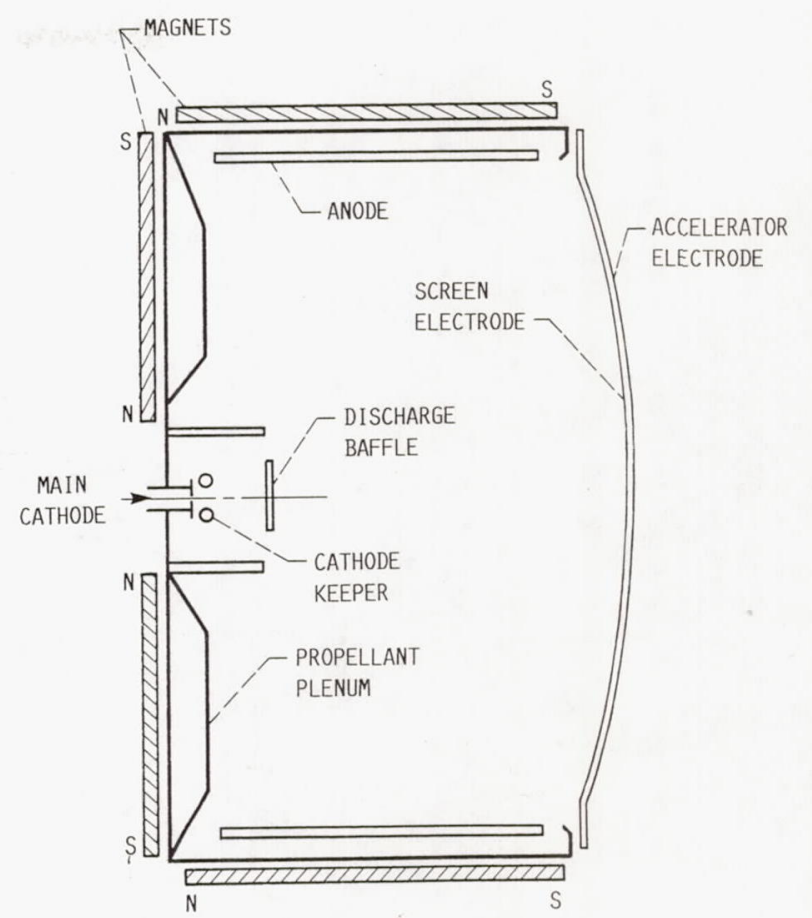

FIGURE 26. - SECTION VIEW OF DIVERGENT MAGNETIC FIELD ION THRUSTER.

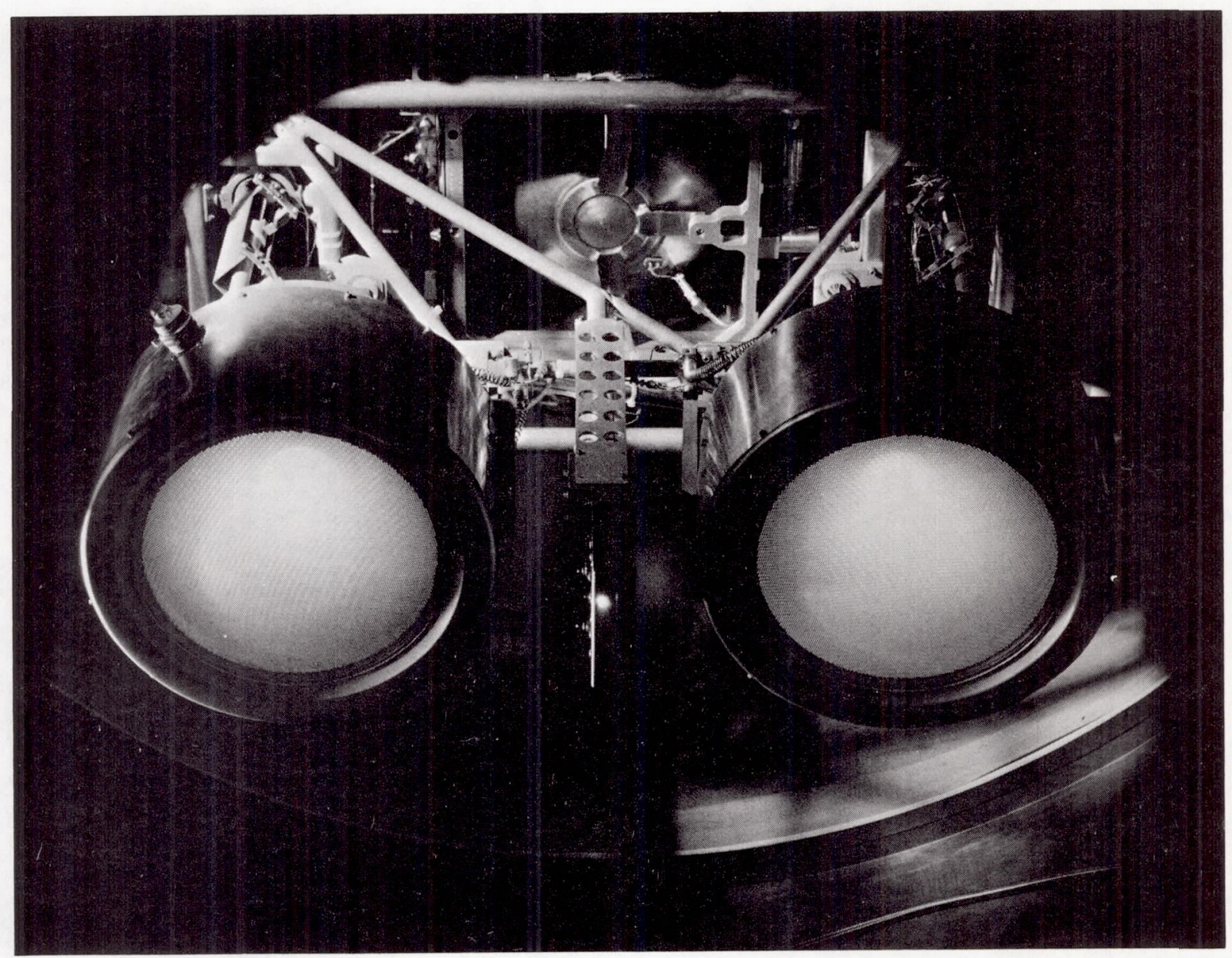

FIGURE 27, - 10-kW XENON ION PROPULSION MODULE. 


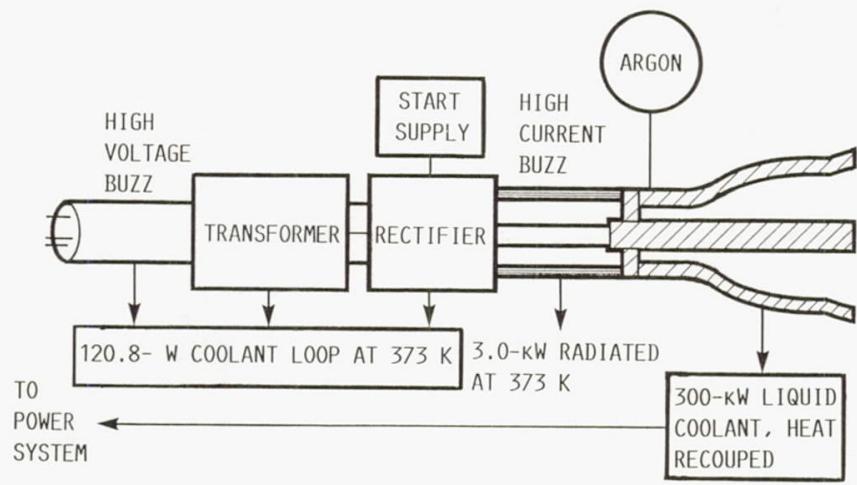

FIGURE 28, - MAGNETOPLASMADYNAMIC THRUSTER SYSTEM COMPONENTS.

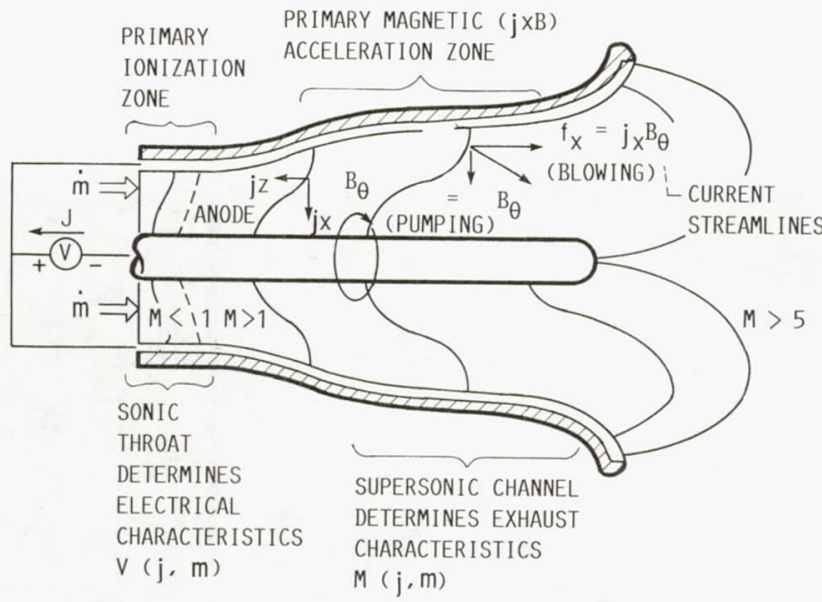

FIGURE 29. - MAGNETOPLASMADYNAMIC (MPD) THRUSTER.

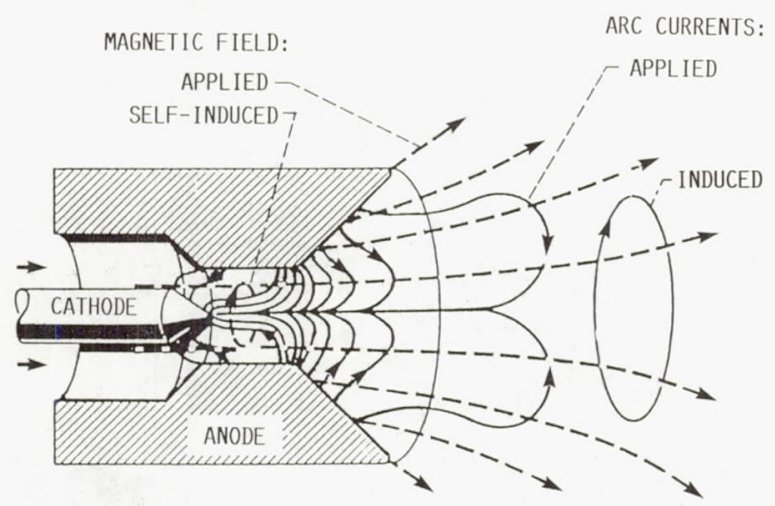

FIGURE 30. - MAGNETOPLASMADYNAMIC ARC THRUSTER CURRENTS AND FIELDS. 


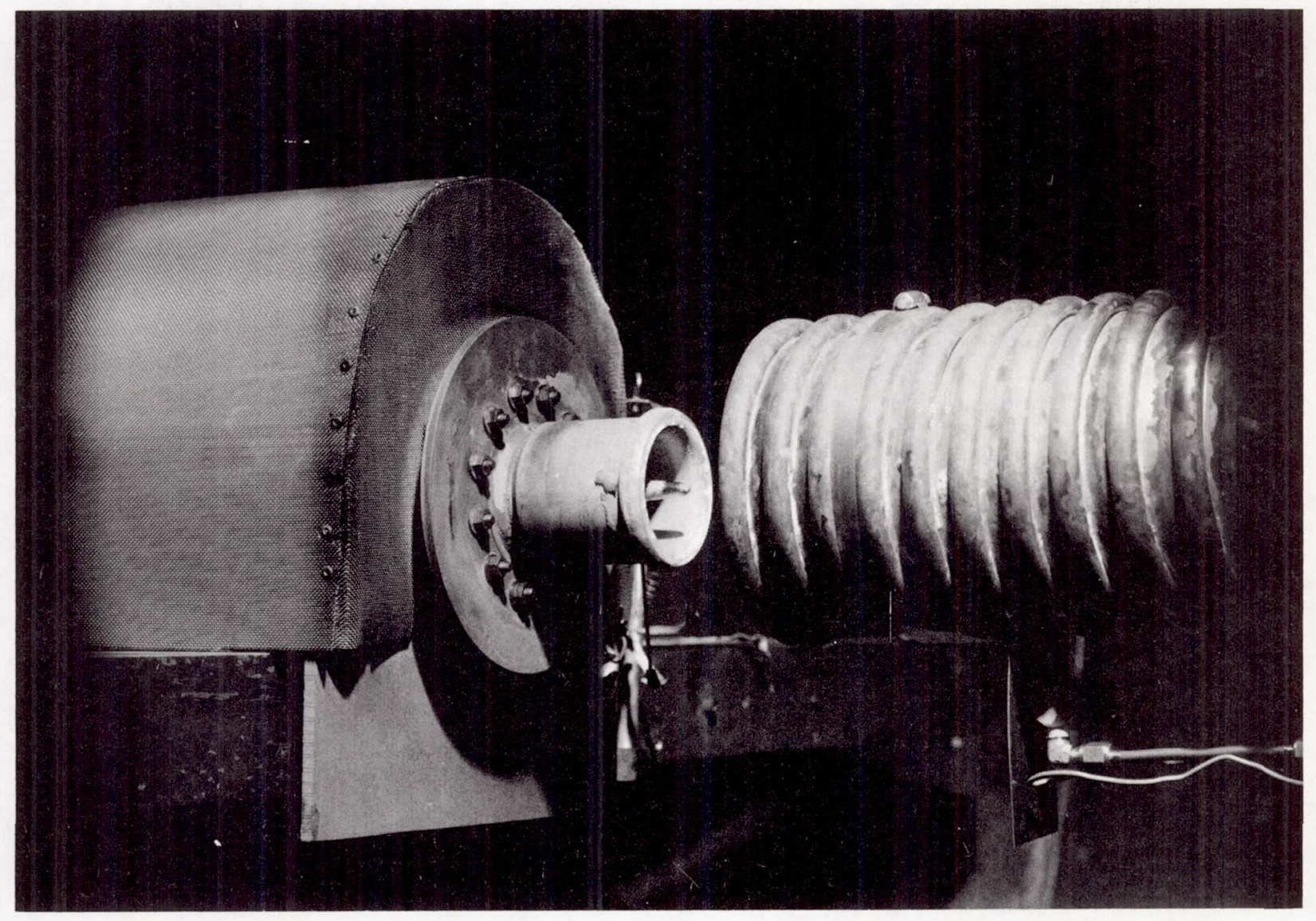

FIGURE 31. - 100-kW SUBSCALE MAGNETOPLASMADYNAMIC THRUS IER. 

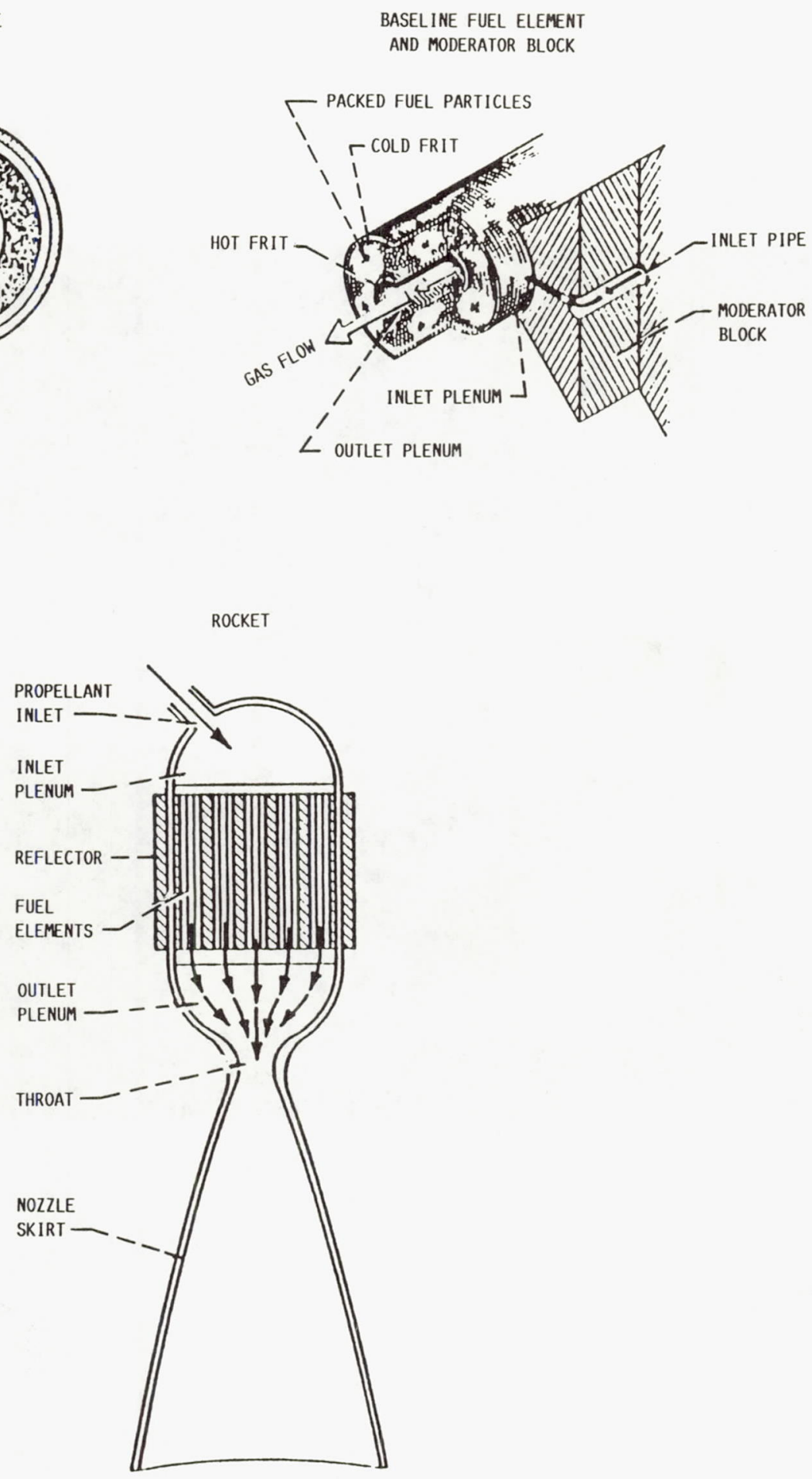

FIGURE 32. - PARTICLE BED, REACTOR-BASED ROCKET CONCEPT. 


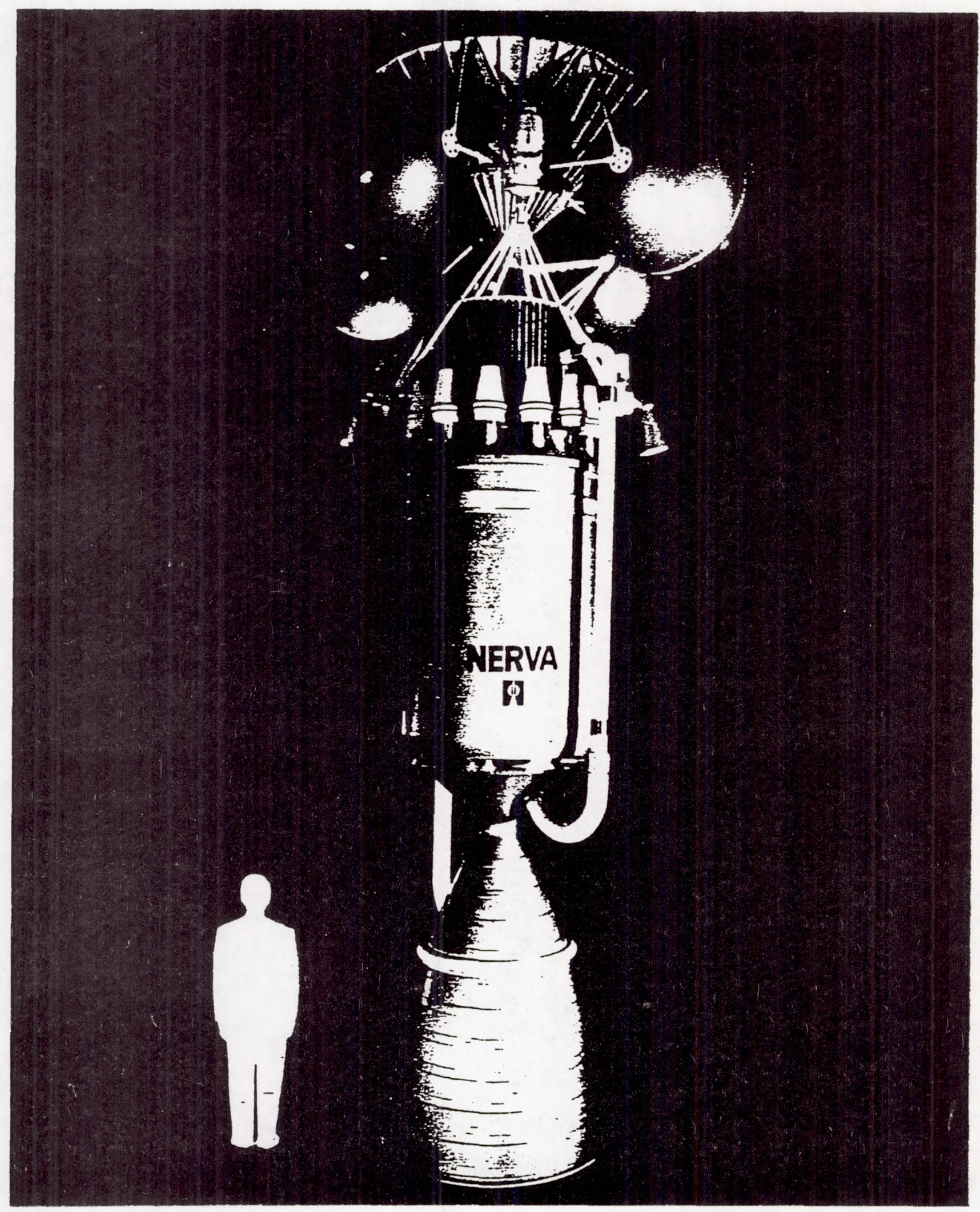

FIGURE 33. - NERVA "FLIGHT ENGINE" CONFIGURATION. 

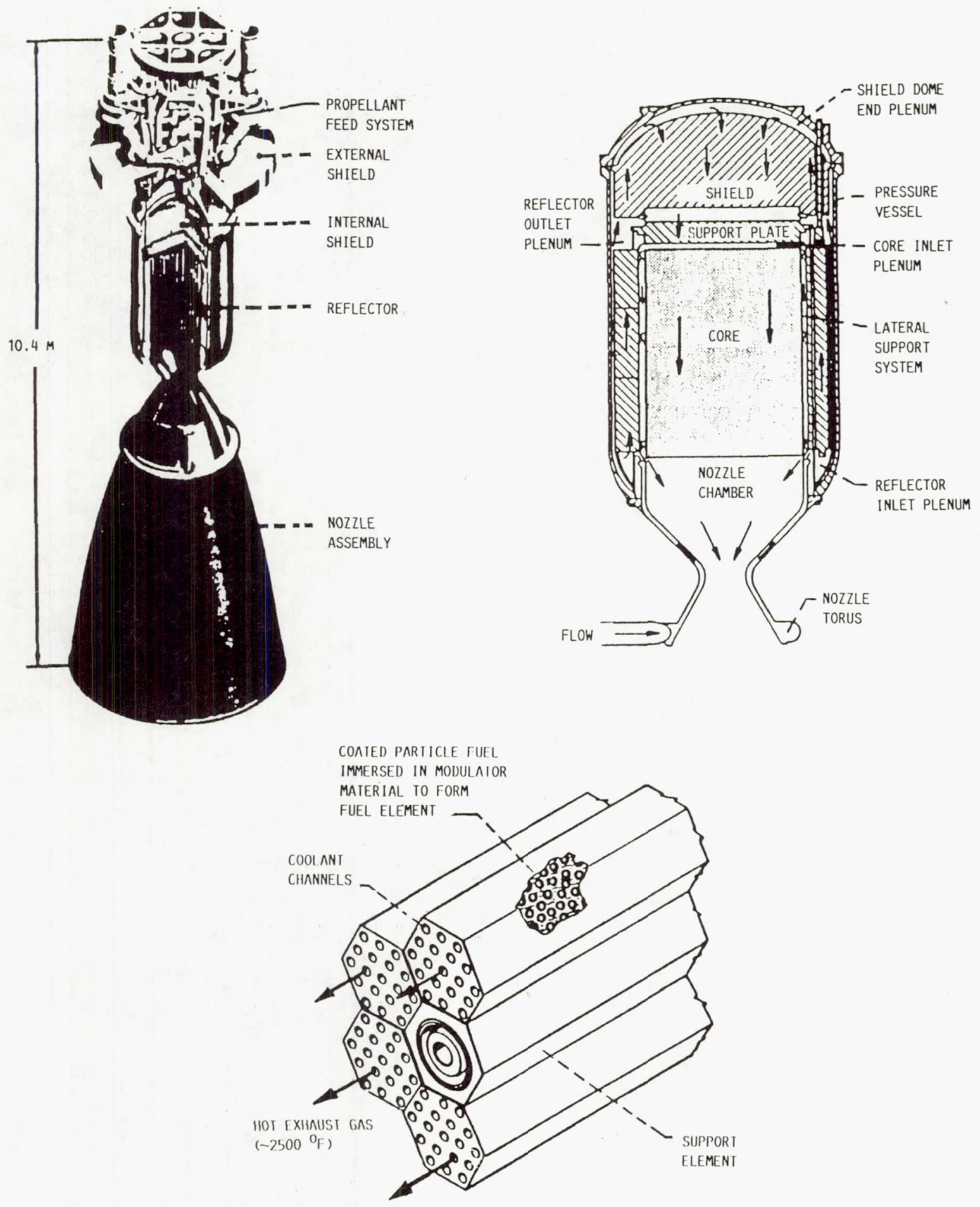

GRAPHIIE MATRIX FUEL ELEMENT CLUSTER

( 1500 FUEL ELEMENTS COMPRISE CYLINDRICAL CORE)

FIGURE 34. - CUT-AWAY AND SCHEMATIC FLOW DESCRIPTION OF THE NERVA BASELINE ENGINE. 


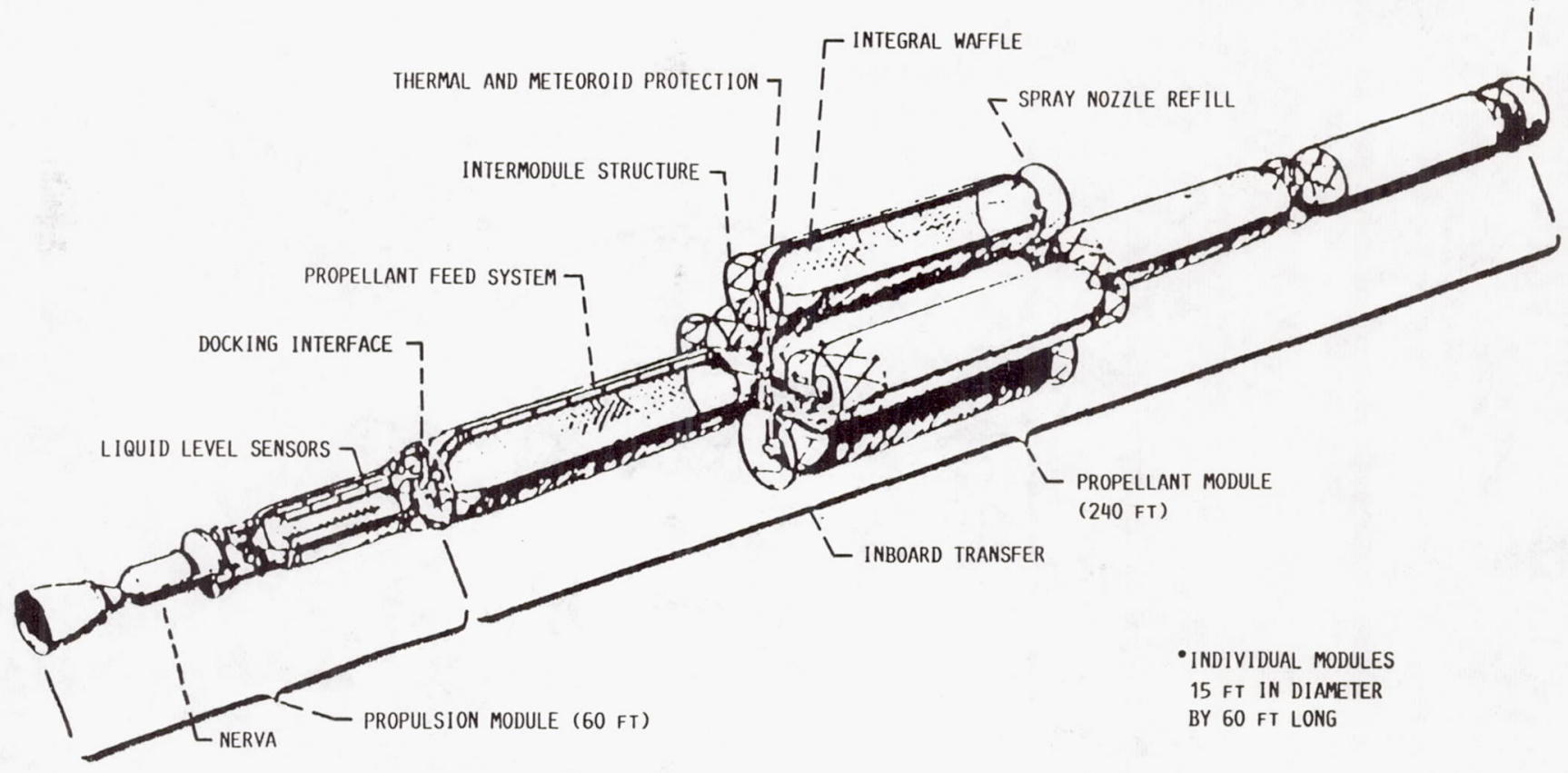

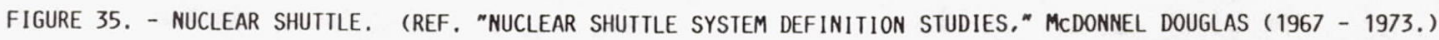

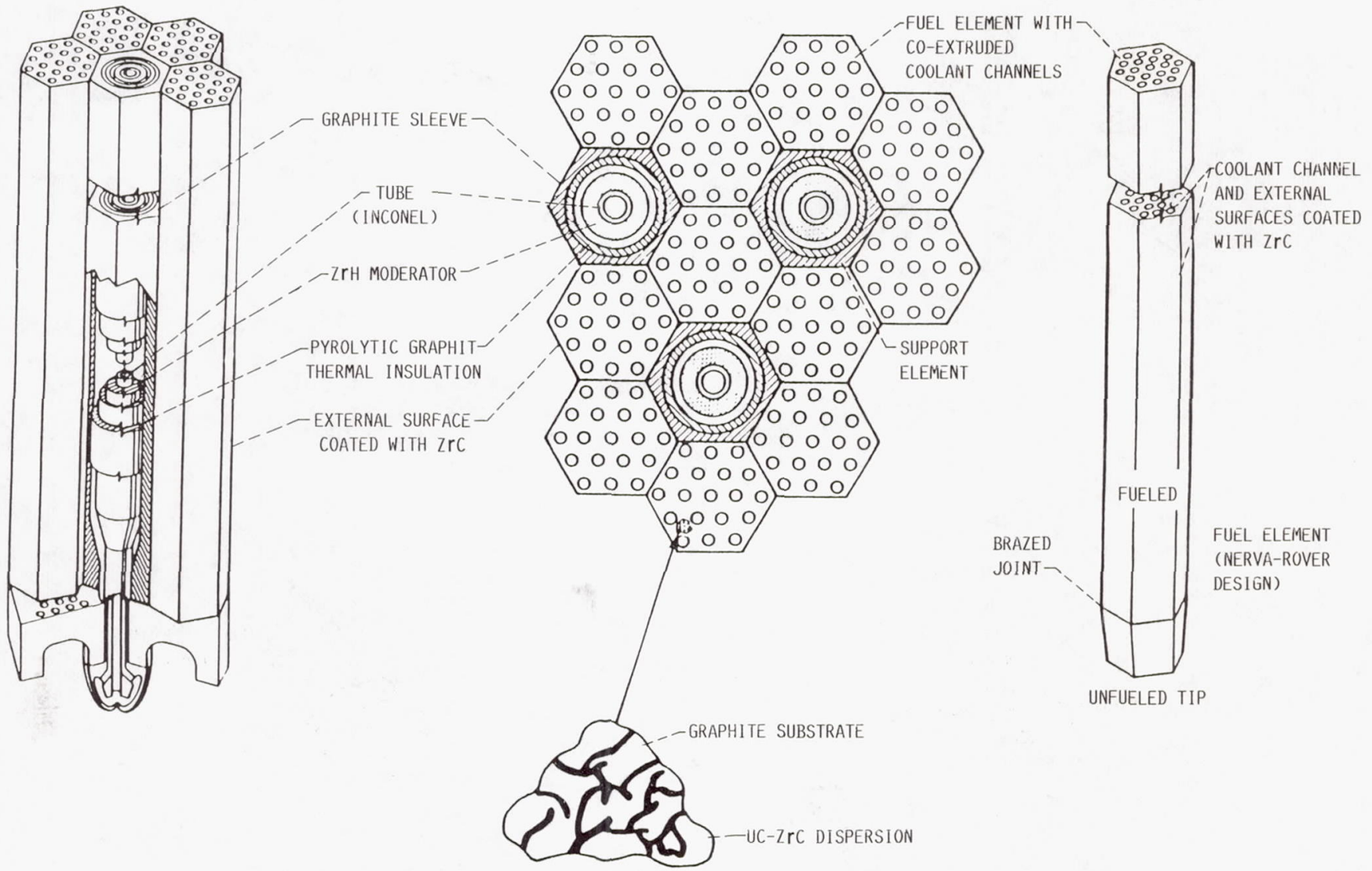

UC-ZrC-C

COMPOSITE MATRIX

FIGURE 36. - NERVA-DERIVATIVE-ROCKET BASED ON PROVEN NERVA-ROVER REACTORS (WESTINGHOUSE). 


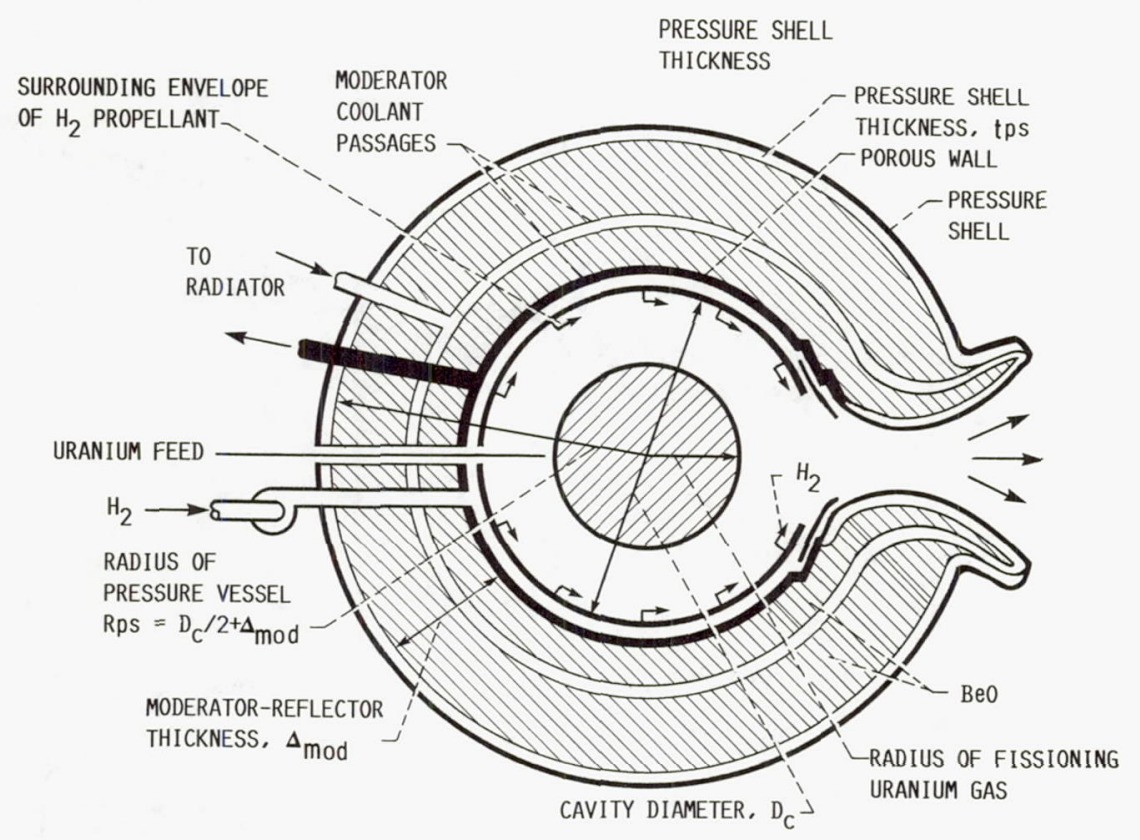

FIGURE 37. - GAS CORE NUCLEAR ROCKET.
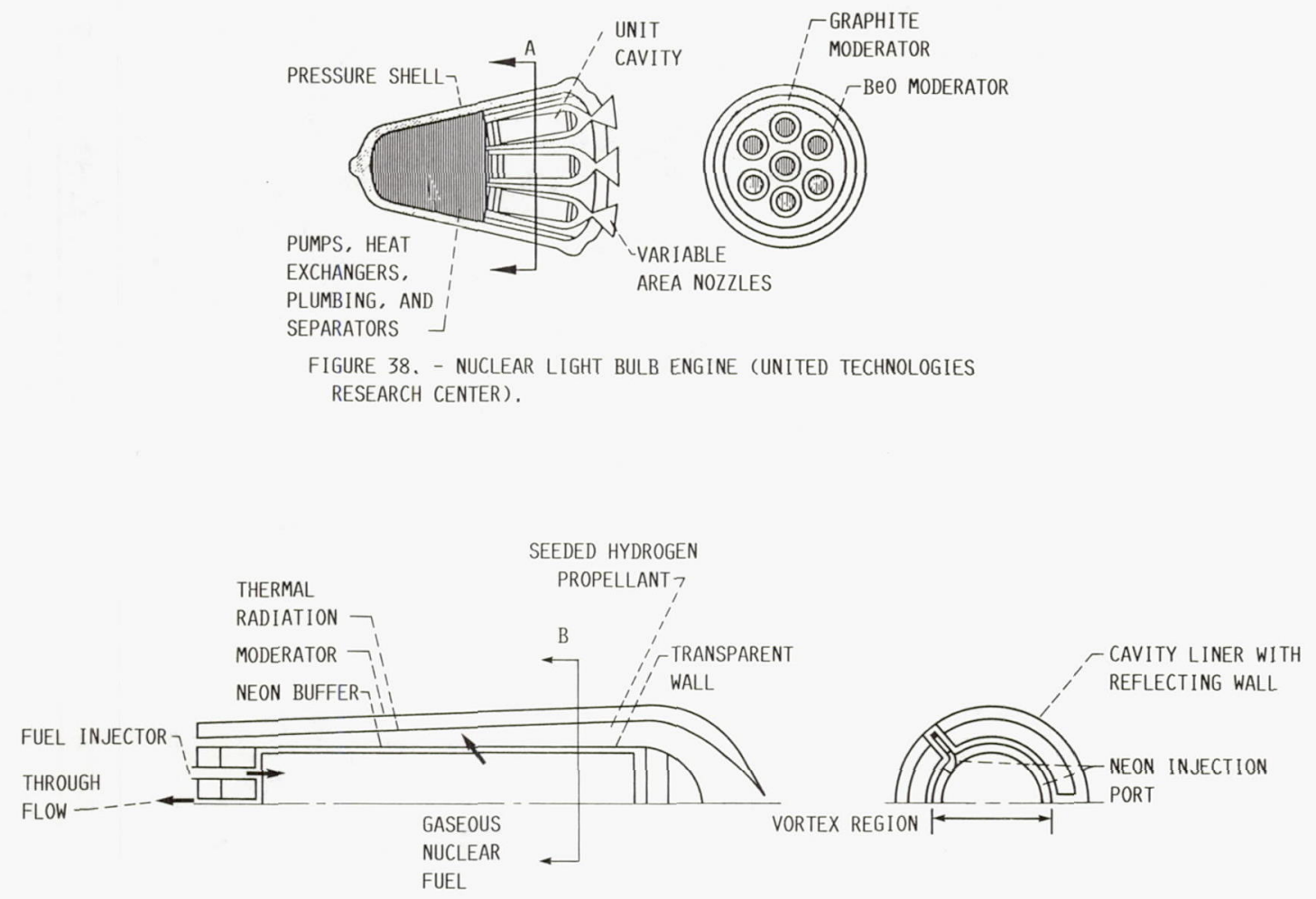

FIGURE 39. - UNIT CAVITY OF A NUCLEAR LIGHT BULB ENGINE (UNITED TECHNOLOGIES RESEARCH CENTER). 


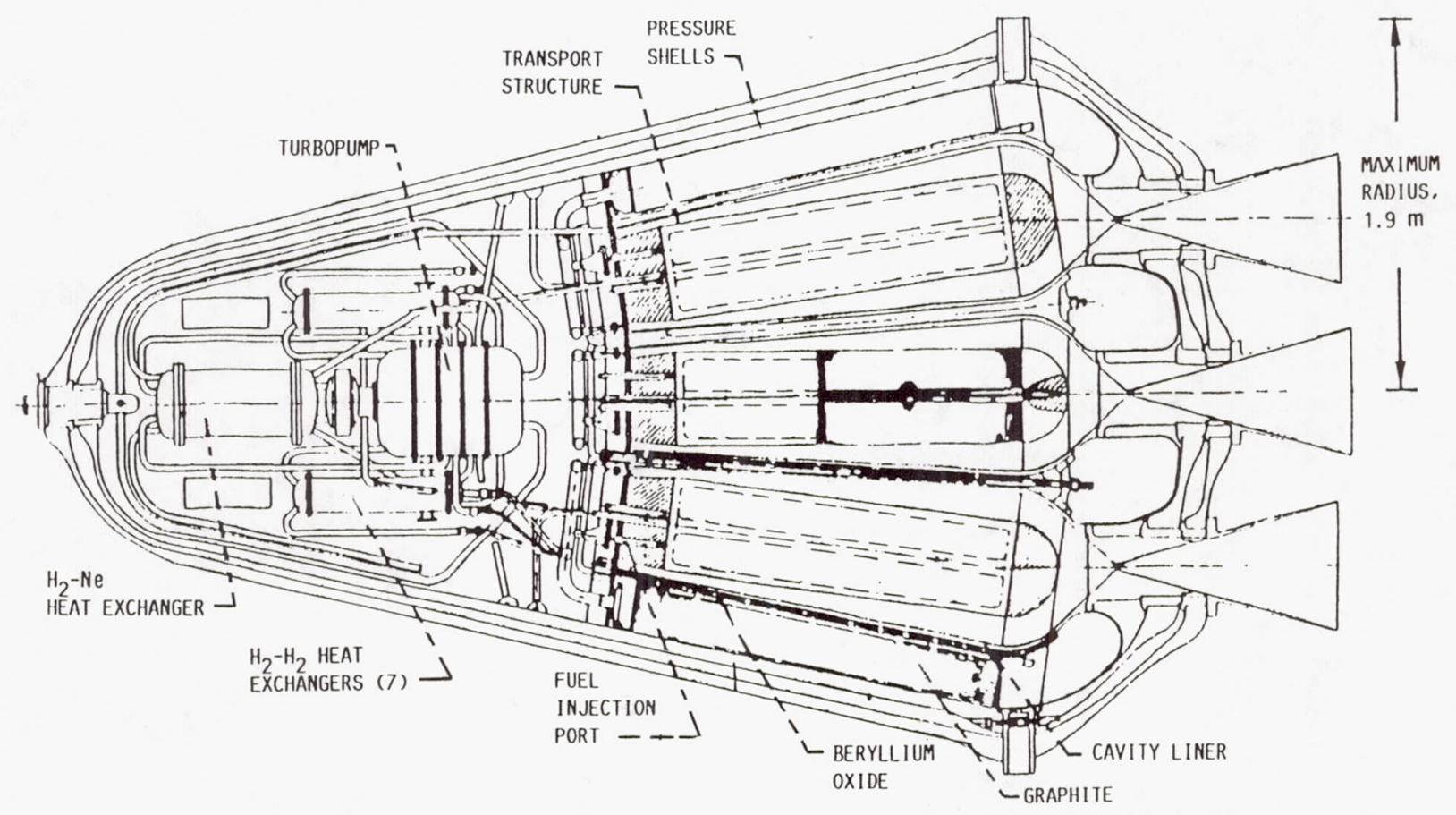

TOTAL. LENGTH, $6.9 \mathrm{~m}$

FIGURE 40. - CROSS SECTION OF NUCLEAR LIGHT BULB ENGINE (UNITED TECHNOLOGIES RESEARCH CENTER).

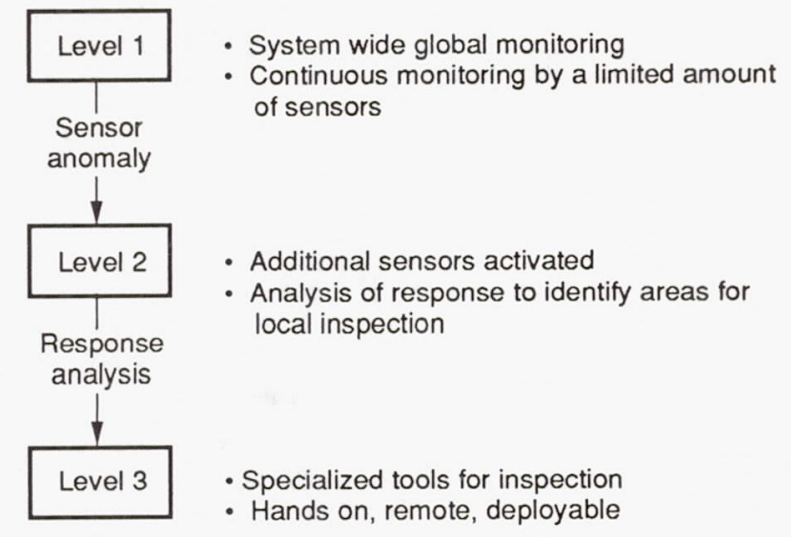

Figure 41.-Three levels of health monitoring for space propulsion systems. 


\begin{tabular}{|c|c|}
\hline Accelerometer & Velocity displacement \\
\hline Acoustic emissions* & Transient events: cracks propagating \\
\hline Borescope* & Visual, cracks, deformation \\
\hline Computed tomography* & $\begin{array}{l}\text { Cracks, porosity, density, wall } \\
\text { thickness }\end{array}$ \\
\hline Deflectometer/goniometer & Shape change, twisting, bending \\
\hline Eddy current* & $\begin{array}{l}\text { Conductivity, chemical changes, dis- } \\
\text { placement, voids, cracks, thickness, } \\
\text { coating thickness }\end{array}$ \\
\hline Fiber optic & $\begin{array}{l}\text { Pyrometry, distance displacement, } \\
\text { vibrations, deformation }\end{array}$ \\
\hline $\begin{array}{l}\text { Interferometry/holography/ } \\
\text { sherography* }\end{array}$ & Displacement, velocity \\
\hline $\begin{array}{l}\text { Spectrophotometer/ } \\
\text { reflectometer }\end{array}$ & $\begin{array}{l}\text { Chemical coating changes, coating } \\
\text { thickness }\end{array}$ \\
\hline Strain gauges & $\begin{array}{l}\text { Residual stress, deformation, cracks, } \\
\text { delaminations }\end{array}$ \\
\hline Thermography* & $\begin{array}{l}\text { Coating absorptivity and emissivity, } \\
\text { bond quality }\end{array}$ \\
\hline Ultrasonic* & $\begin{array}{l}\text { Cracks, delaminations, stress, po- } \\
\text { rosity, thickness, bond quality, grain } \\
\text { size, recrystallization, interlaminar } \\
\text { and "fiber to matrix" bond quality }\end{array}$ \\
\hline X-ray radiography* & $\begin{array}{l}\text { Cracks, debonds, delaminations, } \\
\text { density, porosity }\end{array}$ \\
\hline
\end{tabular}

Figure 42.-NDE tools. 

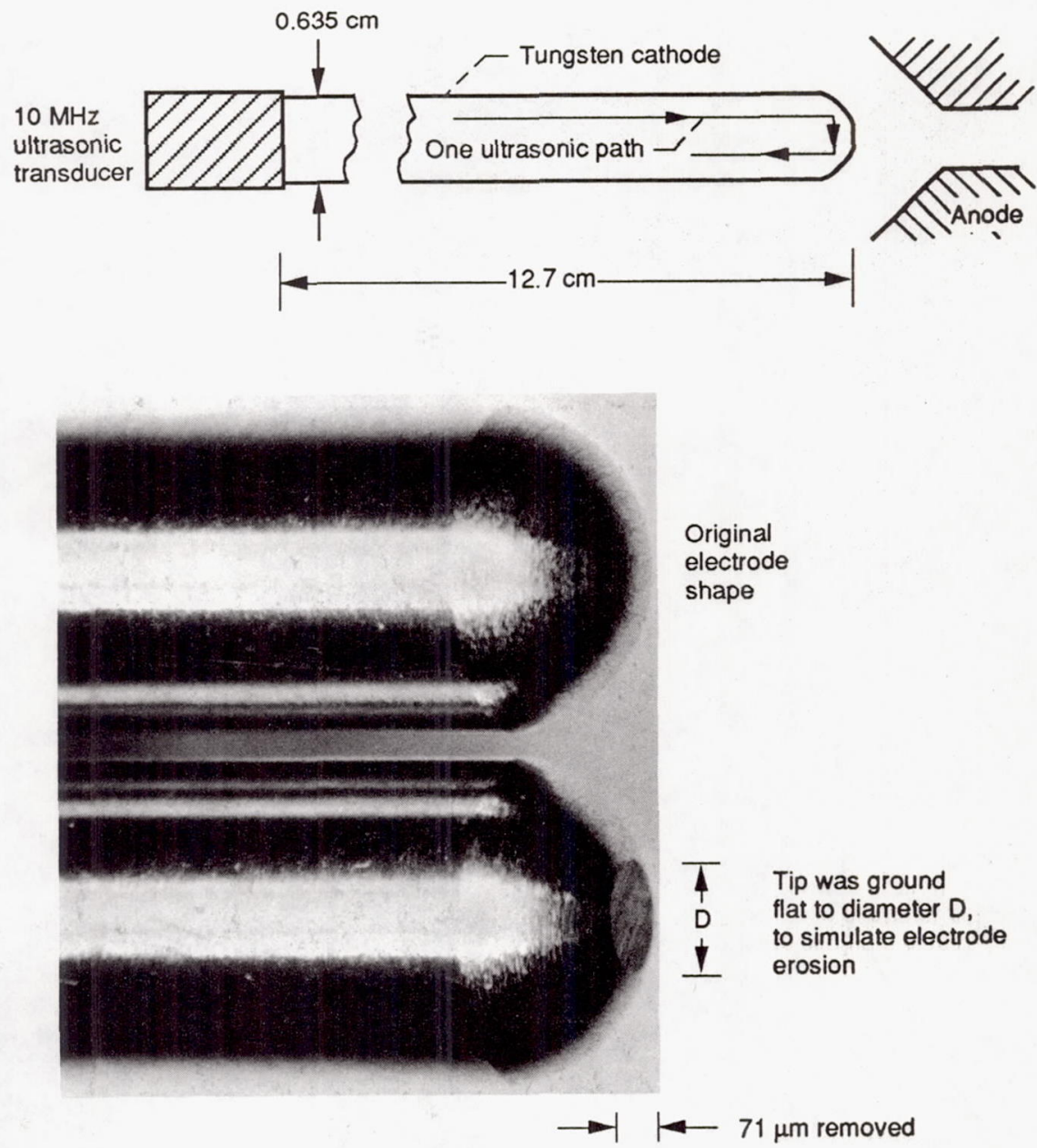

Figure 43.-Feasibility study for health monitoring arcjet electrode.

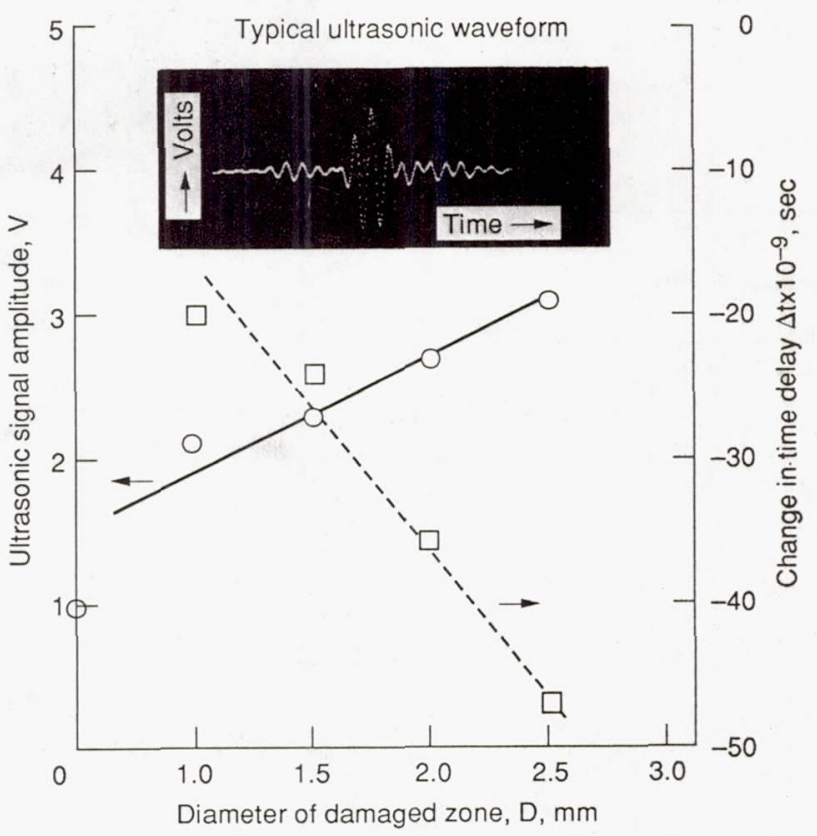

Figure 44.-Ultrasonic evaluation of arcjet electrode. 


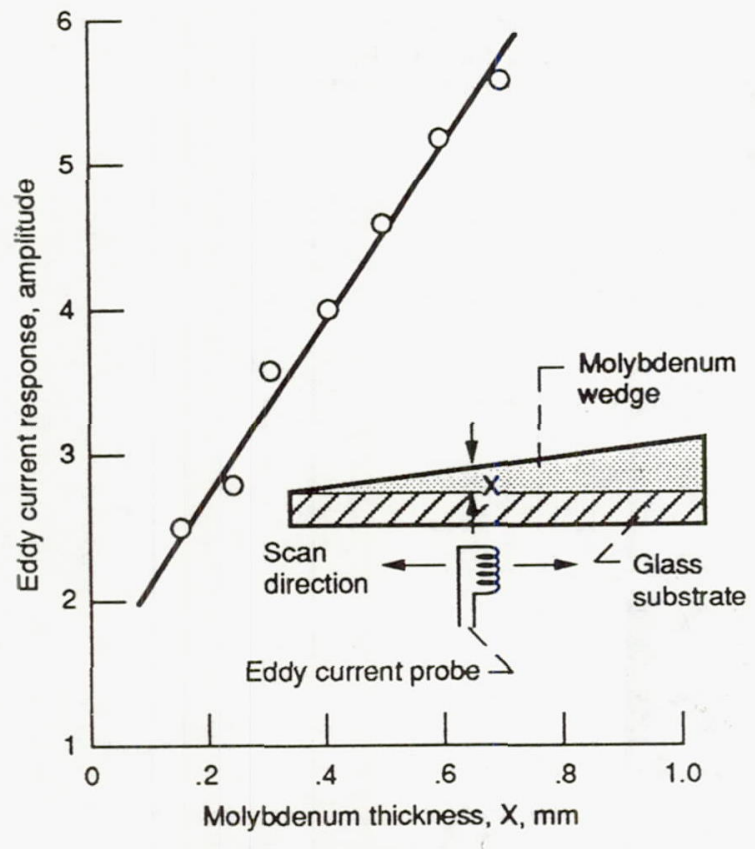

Figure 45.-Eddy current determination of molybdenum film thickness for ion thruster.
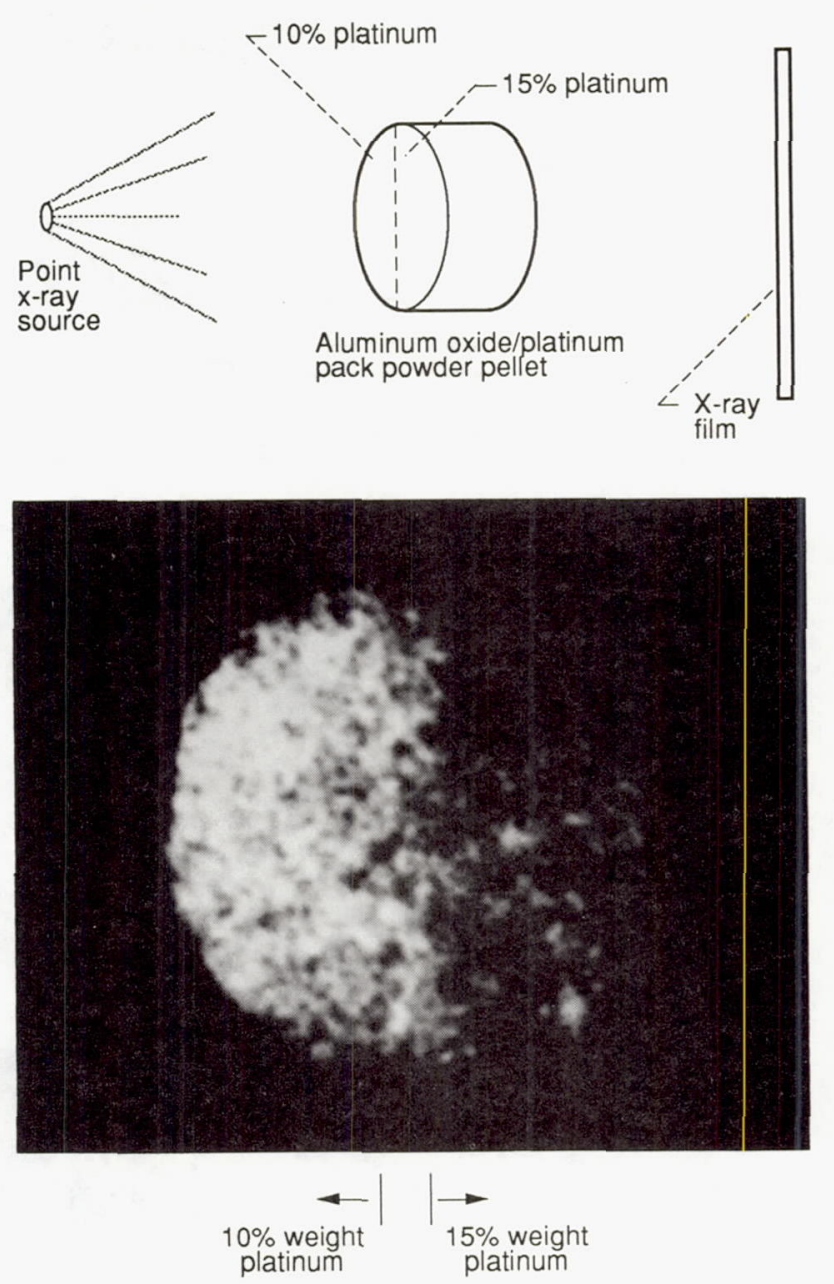

Figure 46.-X-ray radiation monitor for hydrazine catalyst loss. 


\begin{tabular}{|c|c|c|c|c|}
\hline \multicolumn{5}{|c|}{ Report Documentation Page } \\
\hline $\begin{array}{l}\text { 1. Report No. NASA TM }-105164 \\
\text { AIAA - } 91-3433\end{array}$ & \multicolumn{2}{|c|}{ 2. Government Accession No. } & \multicolumn{2}{|c|}{ 3. Recipient's Catalog No. } \\
\hline \multicolumn{3}{|l|}{ 4. Title and Subtitle } & \multirow{2}{*}{\multicolumn{2}{|c|}{ 5. Report Date }} \\
\hline \multicolumn{3}{|c|}{$\begin{array}{l}\text { Nondestructive Evaluation Tools and Experimental Studies } \\
\text { for Monitoring the Health of Space Propulsion Systems }\end{array}$} & & \\
\hline \multirow[t]{2}{*}{$\begin{array}{l}\text { 7. Author(s) } \\
\text { Edward R. Generazio }\end{array}$} & & & \multicolumn{2}{|c|}{$\begin{array}{l}\text { 8. Performing Organization Report No. } \\
\text { E- } 6453\end{array}$} \\
\hline & & & \multicolumn{2}{|c|}{$\begin{array}{l}\text { 10. Work Unit No. } \\
510-01-1 \mathrm{~A}\end{array}$} \\
\hline \multirow{2}{*}{\multicolumn{3}{|c|}{$\begin{array}{l}\text { 9. Performing Organization Name and Address } \\
\text { National Aeronautics and Space Administration } \\
\text { Lewis Research Center } \\
\text { Cleveland, Ohio } 44135-3191\end{array}$}} & \multicolumn{2}{|c|}{ 11. Contract or Grant No. } \\
\hline & & & \multirow{2}{*}{\multicolumn{2}{|c|}{$\begin{array}{l}\text { 13. Type of Report and Period Covered } \\
\text { Technical Memorandum }\end{array}$}} \\
\hline \multicolumn{3}{|c|}{ 12. Sponsoring Agency Name and Address } & & \\
\hline \multicolumn{2}{|c|}{$\begin{array}{l}\text { National Aeronautics and Space Administration } \\
\text { Washington, D.C. } 20546-0001\end{array}$} & & \multicolumn{2}{|c|}{\begin{tabular}{|l} 
14. Sponsoring Agency Code \\
\end{tabular}} \\
\hline \multicolumn{5}{|l|}{ 15. Supplementary Notes } \\
\hline \multicolumn{5}{|c|}{$\begin{array}{l}\text { Prepared for the Conference on Advanced Space Exploration Initiative Technologies cosponsored by the AIAA, NA.SA } \\
\text { and OAI, Cleveland, Ohio, September 4 - 6, 1991. Responsible person, Edward R. Generazio, (216) 433-6018. }\end{array}$} \\
\hline \multicolumn{5}{|c|}{$\begin{array}{l}\text { The next generation of space propulsion systems will be designed to incorporate advanced health monitoring and } \\
\text { nondestructive inspection capabilities. This report provides an overview of background and information on space } \\
\text { propulsion systems at both the programmatic and technical levels. Feasibility experimental studies indicate that } \\
\text { nondestructive evaluation tools such as ultrasonic, eddy current and x-ray may be successfully used to monitor the life } \\
\text { limiting failure mechanisms of space propulsion systems. Encouraging results were obtained for monitoring the life } \\
\text { limiting mechanisms failure for three space propulsion systems; the degradation of tungsten arcjet and magnetoplasma- } \\
\text { dynamic electrodes; presence and thickness of a spallable electrically conducting molybdenum films in ion thrusters; } \\
\text { and the degradation or loss of catalyst in hydrazine thrusters. }\end{array}$} \\
\hline \multicolumn{2}{|c|}{$\begin{array}{l}\text { Nondestructive testing; Nondestructive evaluation; } \\
\text { Propulsion; Ion thrusters; Arcjet; Resistojet; Hydrazine; } \\
\text { X-ray; Magneto-plasma dynamic; Ultrasonic }\end{array}$} & \multicolumn{3}{|c|}{$\begin{array}{l}\text { 18. Distribution Statement } \\
\text { Unclassified - Unlimited } \\
\text { Subject Category } 38\end{array}$} \\
\hline $\begin{array}{l}\text { 19. Security Classif. (of the report) } \\
\text { Unclassified }\end{array}$ & 20. Security Classi & $\begin{array}{l}\text { his page) } \\
\text { ssified }\end{array}$ & $\begin{array}{r}\text { 21. No. of pages } \\
44\end{array}$ & $\begin{array}{r}\text { 22. Price* } \\
\text { A03 }\end{array}$ \\
\hline
\end{tabular}


National Aeronautics and

Space Administration

Lewis Research Center

Cleveland, Ohio 44135

Official Business

Penalty for Private Use $\$ 300$

FOURTH CLASS MAIL

ADDRESS CORRECTION REQUESTED
|||||

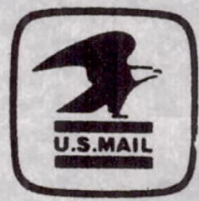

Poslage and Fees Paid

Natıonal Aeronautics and

Space Administration

NASA 451 